\title{
Evidence for km-scale Neogene exhumation driven by compressional deformation in the Irish Sea basin system
}

Simon P. Holford ${ }^{1}$, Paul F. Green ${ }^{2}$, Jonathan P. Turner ${ }^{1}$, Gareth A. Williams ${ }^{3}$, David R. Tappin ${ }^{3} \&$ Ian R. Duddy ${ }^{2}$

${ }^{1}$ School of Geography, Earth \& Environmental Sciences, University of Birmingham, Edgbaston, Birmingham, B15 2TT, UK (e-mail: sph184@bham.ac.uk)

${ }^{2}$ Geotrack International Pty Ltd, 37 Melville Road, West Brunswick, Victoria 3055, Australia

${ }^{3}$ British Geological Survey, Keyworth, Nottingham, NG12 5GG, UK

\section{Abstract}

Large tracts of the NW European continental shelf and Atlantic margin have experienced km-scale exhumation during the Cenozoic, the timing and causes of which are debated. There is particular uncertainty about the exhumation history of the Irish Sea basin system, Western UK, which has been suggested to be a focal point of Cenozoic exhumation across the NW European continental shelf. Many studies have attributed the exhumation of this region to processes associated with the early Palaeogene initiation of the Iceland Plume, whilst the magnitude and causes of Neogene exhumation have attracted little attention. However, the sedimentary basins of the southern Irish Sea contain a mid-late Cenozoic sedimentary succession up to $1.5 \mathrm{~km}$ in thickness, the analysis of which should permit the contributions of Palaeogene and Neogene events to the Cenozoic exhumation of this region to be separated. In this paper, an analysis of the palaeothermal, mechanical and structural properties of the Cenozoic succession is presented with the aim of quantifying the timing and magnitude of Neogene exhumation, and identifying its ultimate causes. Synthesis of an extensive apatite fission-track analysis (AFTA), vitrinite reflectance (VR) and compaction (sonic velocity and density log-derived porosities) database shows that the preserved Cenozoic sediments in the southern Irish Sea were more deeply buried by up to $1.5 \mathrm{~km}$ of additional section prior to exhumation which began between 20 and $15 \mathrm{Ma}$. Maximum burial depths of the preserved sedimentary succession in the St. George's Channel Basin were reached during mid-late Cenozoic 
times meaning that no evidence for early Palaeogene exhumation is preserved whilst AFTA data from the Mochras borehole (onshore NW Wales) show that early Palaeogene cooling (i.e. exhumation) at this location was not significant. Seismic reflection data indicate that compressional shortening was the principal driving mechanism for the Neogene exhumation of the southern Irish Sea. Coeval Neogene shortening and exhumation is observed in several sedimentary basins around the British Isles, including those along the UK Atlantic margin. This suggests that the forces responsible for the deformation and exhumation of the margin may also be responsible for the generation of $\mathrm{km}$-scale exhumation in an intraplate sedimentary basin system located $>1000 \mathrm{~km}$ from the most proximal plate boundary. The results presented here show that compressional deformation has made an important contribution to the Neogene exhumation of the NW European continental shelf.

\section{Introduction}

The NE Atlantic margin and large portions of the surrounding continental hinterlands have experienced substantial uplift and erosion (exhumation) during the Neogene which has profoundly influenced the distribution and morphology of the present-day landmasses (Doré et al. 1999) and exerted a critical control on prospectivity in many petroliferous sedimentary basins across this region (Doré et al. 2002a). At present the exact causes of this exhumation are poorly constrained (e.g. Rohrman \& van der Beek 1996; Stuevold \& Eldholm 1996; Japsen \& Chalmers 2000; Doré et al. 2002b; Japsen et al. 2005, in press; Praeg et al. 2005). Suggested tectonic causes of this exhumation are varied, and include compressional deformation induced by Atlantic ridge-push and Alpine collisional forces (Cloetingh et al. 1990; Lundin \& Doré 2002), lithospheric flexure (Redfield et al. 2005), and dynamic uplift supported by the Iceland mantle plume (Mackay et al. 2005), asthenospheric diapirism (Rohrman \& van der Beek 1996) or evolving patterns of mantle convection following continental breakup (Praeg et al. 2005). A major problem in determining the origin of the uplift lies in separating the effects of Neogene exhumation from those of earlier events, in the late Mesozoic and Palaeogene (Japsen \& Chalmers 2000; Japsen et al. 2005; Holford et al. 2005a). 
In recent years, considerable attention has been paid to the late Mesozoic-Cenozoic exhumation history of the British Isles (Lewis et al. 1992; Brodie \& White 1994; Cope 1994; Hillis 1995; Japsen 1997; White \& Lovell 1997; Rowley \& White 1998; Green et al. 2002; Ware \& Turner 2002; Holford et al. 2005b). A great deal of this discussion has been presented in terms of Palaeogene uplift, which has been assumed to represent the dominant exhumation episode. Consequently, the magnitude and timing of late Cenozoic/Neogene exhumation across this region is poorly resolved (Praeg et al. 2005; Stoker et al. 2005). This imbalance is typified by studies of the exhumation history of the Irish Sea basin system. Numerous workers have cited this suite of intraplate sedimentary basins as the locus of Cenozoic exhumation across the British Isles, and indeed, the NW European continental shelf (Lewis et al. 1992; Chadwick et al. 1994; Brodie \& White 1995; White \& Lovell 1997; Jones et al. 2002). Many workers have suggested that the main phase of exhumation in the Irish Sea occurred during early Palaeogene times, with the uplift caused by the isostatic response to magmatic underplating of the lower crust, associated with the initiation of the Iceland Plume (Brodie \& White 1994; White \& Lovell 1997; Rowley \& White 1998; Al-Kindi et al. 2003; Tiley et al. 2004). Much of this research has focused on the East Irish Sea Basin (EISB), where early applications of apatite fission-track analysis $\left(\mathrm{AFTA}^{\circledR}\right)$ revealed that samples close to the sea bed today had resided at elevated palaeotemperatures in excess of $100^{\circ} \mathrm{C}$ prior to early Palaeogene (65-60 Ma) cooling. This cooling was interpreted in terms of the removal of a thick (up to $3 \mathrm{~km}$ ) cover of Mesozoic sediments (Lewis et al. 1992). Subsequent work in this basin however, aided by both a substantially enlarged dataset and methodological advances, has demonstrated the importance of advective fluid-related heating and periods of elevated basal heat flow, implying that the elevated palaeotemperatures recorded by AFTA cannot be interpreted in terms of heating due solely to deeper burial (Green et al. 1997; Green 2002; Holford et al. 2005a). Since the youngest pre-Quaternary sediments in the EISB are Lower Jurassic in age (Jackson \& Mulholland 1993) minimal stratigraphic constraints can be placed upon the timing and magnitude of late Mesozoic-Cenozoic exhumation; the top Mesozoic unconformity in this basin is in all likelihood a composite feature which records at least three separate pulses of uplift and erosion (Holford 2006). 
Given the existence of a thick sequence of Cenozoic sedimentary rocks in the basins of the southern Irish Sea, it is perhaps surprising that relatively few studies have exploited this in order to provide insights into the exhumation history of the wider region. The Cardigan Bay Basin (CBB) contains c. $0.5 \mathrm{~km}$ of Oligocene-Miocene sediments, whilst a c. $1.5 \mathrm{~km}$ thick succession of Eocene-Oligocene sediments can be found in the contiguous St. George's Channel Basin (SGCB) (Tappin et al. 1994) (Fig. 1). The analysis of the burial and exhumation history of these Cenozoic sediments should permit the effects of late Cenozoic exhumation to be separated from those of earlier events. The principal aims of this paper therefore are to assess whether the Cenozoic sedimentary succession in the southern Irish Sea has been more deeply buried in the past, and if so, to determine when the exhumation occurred and what its underlying causes were. A diverse range of techniques are employed to address these issues. Palaeothermal (AFTA and vitrinite reflectance (VR)) and compaction (sonic velocity and density log-derived porosities) data are used to quantify the amounts by which the Cenozoic (and underlying Mesozoic) rocks of the CBB and SGCB have been more deeply buried prior to exhumation. AFTA data combined with stratigraphical constraints have been used to determine the timing of exhumation (cf. Green et al. 2002). Finally, a dense grid of high resolution, well-calibrated 2D seismic reflection data is used to assess the structural properties of the Cenozoic fill of the SGCB.

Our investigations reveal that the preserved Cenozoic rocks in the southern Irish Sea have been more deeply buried by up to 1 to $1.5 \mathrm{~km}$ of additional sedimentary section, prior to exhumation which began between 25 and 15 Ma (based on a regional synthesis of AFTA data). Seismic reflection data show that the principal cause of this exhumation episode was the compressional shortening and resultant thickening and uplift of the Cenozoic sedimentary fill of these basins. Given that his compression and exhumation is coeval with intense Neogene compressional deformation observed along the Atlantic margin and in the Alpine foreland, it is likely to be a function of compressional stresses generated by both Atlantic ridge-push and Alpine lithospheric shortening. This paper therefore provides a good example of km-scale exhumation across a continental interior setting which can at least in part be attributed to plate boundary forces. 


\section{The Mesozoic-Cenozoic geological record in the southern Irish Sea}

The Irish Sea basin system comprises a suite of mostly offshore extensional sedimentary basins which was initiated during the Permian-Triassic (Coward 1995), largely exploiting pre-existing Precambrian, Caledonian and Variscan structural trends (Tappin et al. 1994; Welch \& Turner 2000). Interspersed periods of rifting, thermal subsidence and uplift have resulted in a variable post-Palaeozoic stratigraphic record across this region (Tappin et al. 1994). In this paper, the southern Irish Sea basin system refers to the en-echelon CBB and SGCB (Fig. 1). These basins are flanked by the neighbouring Central Irish Sea Basin to the NW, the burial and exhumation of which has previously been studied in detail by Duncan et al. (1998) and Green et al. (2001a).

Although the principal concern of this contribution is the Cenozoic sedimentary succession preserved in the southern Irish Sea area, it should be mentioned that the CBB and SGCB contain considerable thicknesses of Mesozoic sediments. The Mochras borehole, which penetrated the sedimentary fill of the CBB, encountered the thickest known sequence of Lower Jurassic sediments in the British Isles at $1305 \mathrm{~m}$ (Woodland 1971; Hallam 1992). The contiguous SGCB contains an even thicker Jurassic succession, with seismic reflection data indicating that greater than $5 \mathrm{~km}$ of Jurassic rocks, and possibly even Lower Cretaceous deposits, are preserved in the deepest parts of the basin (Tappin et al. 1994; Welch \& Turner 2000). This is in marked contrast to the stratigraphy of the more northerly EISB where, with the exception of several Lower Jurassic outliers, the youngest preserved pre-Quaternary rocks are generally Late Triassic (Mercia Mudstone Group) in age (Jackson et al. 1995).

The Mesozoic rocks of the $\mathrm{CBB}$ and SGCB are overlain, often with marked unconformity, by Cenozoic sediments which attain a thickness of $0.52 \mathrm{~km}$ in the CBB at Mochras, and locally exceed $1.5 \mathrm{~km}$ in the SGCB (Tappin et al. 1994; Williams et al. 2005). The Cenozoic succession at Mochras comprises interbedded mudstones and siltstones with subordinate lignites and several thick conglomeratic units towards the base (Fig. 2) (Woodland 1971; O’Sullivan 1979), and has been assigned a Middle Oligocene to Lower Miocene age by Herbert-Smith (1979) on the basis of 
palynological data. The Cenozoic sediments of the SGCB are penetrated by four wells which encountered Eocene-Oligocene sands, silts, clays and lignites that show a marked similarity to those samples in the Mochras borehole (Tappin et al. 1994). The sediments from both basins are indicative of deposition in nonmarine, alluvialdominated environments (Dobson \& Whittington 1987; Tappin et al. 1994). In terms of its relation to regional fault systems, Williams et al. (2005) interpreted the SGCB as a large transtensional basin located at a releasing stepover on a major NW-SE trending Mesozoic-Cenozoic strike-slip fault system comprising the Codling and Sticklepath Faults. Dextral displacements along this fault system also led to the formation of Eocene-Oligocene transtensional basins containing similar deposits in SW England, Central Irish Sea Basin and Northern Ireland (Izatt et al. 2001; Cunningham et al. 2004; Ziegler 2004). In the southern Irish Sea, the transfer of displacement between the Sticklepath and Codling faults was accommodated by normal movements along the Mochras-St. George's Channel-Bala fault system (Turner 1997; Holford et al. 2005b; Williams et al. 2005). The CBB has the form of a southeasterly deepening half-graben downfaulted against the Lower Palaeozoic Welsh Massif following normal displacements along the Mochras Fault (Tappin et al. 1994) (Fig. 3).

The provenance of the Cenozoic deposits of the southern Irish Sea is uncertain. Lower Palaeozoic clasts are found in the base of the Mochras borehole (Tappin et al. 1994), although these may record more local footwall uplift and erosion in NW Wales rather than more regional uplift and exhumation across Wales (Holford et al. 2005a; Holford 2006). Fission-track studies in northern England demonstrate considerable exhumation across this region which began between 65 and 55 Ma (Green 2002, 2005). The proposal by Dobson \& Whittington (1987) that the Cenozoic sediments of the southern Irish Sea were deposited on the floodplain of a highly sinuous southwesterly flowing river system is consistent with the suggestion of a northeasterly sediment source.

\section{Methods used to reconstruct magnitudes and timing of exhumation}

Most techniques available for the estimation of exhumation in sedimentary basins utilise 'point' measurements (i.e. local estimates for an individual well or borehole) of 
vertical rock displacement relative to a specified frame of reference (Corcoran \& Doré 2005). In this study the main frames of reference used to estimate exhumation are thermal (e.g. apatite fission-track analysis (AFTA) and vitrinite reflectance (VR) and compactional (e.g. formation density and sonic velocity from wireline log data).

Compaction-driven porosity reduction is an effective and widely used measure of former burial depths in sedimentary basins (Hillis 1991, 1995; Japsen 2000; Ware \& Turner 2002). The term compaction refers to the three-dimensional reduction in sediment volume which occurs as a result of mechanical and thermochemical processes during burial (Giles et al. 1998; Corcoran \& Doré 2005). Compaction is generally expressed by the reduction of porosity with burial depth, although it is important to note that porosity reduction can also be caused by increases in solid volume (i.e. by cementation) in addition to volume strains (Giles et al. 1998). In order to estimate the magnitude of exhumation at a well or borehole using compaction data, it is first necessary to establish a reference porosity-depth curve (i.e. one in which the entire succession is presently at its maximum burial depth, and pressure is hydrostatic (Japsen et al. 2002)). This is usually constructed from 'normally buried', unexhumed parts of a basin, or if the entire basin has been affected by exhumation, then a reference trend from a different, unexhumed basin can be used, as long as the reference trend has been constructed for a sufficiently similar lithology (Corcoran \& Doré 2005). Sedimentary successions in exhumed basins will exhibit anomalously low porosities with respect to their present-day burial depth.

Studies of maximum burial depths conducted in the thermal reference frame exploit the progressive increase of temperature with depth within the lithosphere. Sedimentary units are progressively heated during burial and begin to cool at the initiation of exhumation (Green et al. 2002). AFTA and VR provide quantitative constraints upon the temperatures attained by a rock sample at a palaeothermal maximum, prior to the onset of cooling (Green et al. 2002). The analysis of AFTA and VR samples over a range of depths in an exploration well or borehole reveals the variation of maximum palaeotemperature with depth. The form of the palaeotemperature profile characterizing a particular palaeothermal episode can provide vital information on the likely mechanisms of heating and cooling; heating caused solely by deeper burial should result in an approximately linear 
palaeotemperature profile with a similar value to the present-day geothermal gradient (e.g. Duddy et al. 1994; Green et al. 2002). The extrapolation of a fitted palaeogeothermal gradient, above an appropriate unconformity and to an assumed palaeosurface temperature, provides an estimate of the amount by which the rock succession preserved beneath that unconformity was more deeply buried prior to exhumation. Using maximum likelihood theory, the ranges of values for both the palaeogeothermal gradient and thickness of additional sedimentary section which are consistent with the measured palaeotemperature constraints can be defined within 95\% confidence limits (Bray et al. 1992).

Of the multitude of techniques available for reconstructing the exhumation histories of sedimentary basins (e.g. Corcoran \& Doré 2005), AFTA is perhaps the most useful because it can provide an independent estimate of the time at which a rock sample began to cool from its maximum palaeotemperature, or a subsequent palaeotemperature peak. If the cooling can be attributed to exhumation AFTA can consequently be used to constrain the timing of the onset of exhumation (Green et al. 2002). Since AFTA only provides information on the temperature-time history of a rock sample below a critical temperature limit of $>110-120^{\circ} \mathrm{C}$ (i.e. the temperature at which at which all tracks are 'totally annealed' such that track lengths are reduced to zero) (Green et al. 1986, 2002), AFTA data are especially useful in conjunction with VR data which allows estimation of higher maximum palaeotemperatures (Duddy et al. 1994). Given that the key aspects of the thermal history which control the development of the AFTA parameters (i.e. the track length distribution and fissiontrack age) are the maximum palaeotemperature of the sample, and the time at which cooling from that temperature began, the approach adopted in this study focuses on constraining these key parameters, rather than attempting to constrain the entire thermal history of each apatite sample (Green et al. 2002). Wherever possible, AFTA data from each sample have been interpreted in terms of two or three episodes of heating and cooling, using assumed heating and cooling rates. Our modelling approach also makes full quantitative allowance for the important effects of chlorine content on the annealing kinetics of fission tracks in apatite (Green et al. 1986, 2005). Full descriptions of the analytical and interpretative procedures by which thermal history solutions are derived from AFTA and VR data are provided by Green et al. (2001b, 2002). 
All techniques available for the estimation of exhumation in sedimentary basins are subject to various uncertainties (Corcoran \& Doré 2005), that are magnified in regions such as the Irish Sea basin system which have experienced complex geological histories characterised by repeated cycles of burial and exhumation (Green et al. 2002; Holford et al. 2005b). The diverse approach adopted in this study, whereby both palaeothermal and compactional proxies are used to reconstruct former burial depths and integrated with seismic data, has the advantage of improving the precision of estimates of the timing and magnitude of exhumation, and, if the estimates from the independent techniques show a high degree of consistency, this serves to validate the use of methods such as AFTA, VR and compaction analyses as valuable tools for reconstructing the burial and exhumation histories of sedimentary basins.

\section{Mesozoic-Cenozoic burial and exhumation at Mochras, Cardigan Bay Basin}

In this section, palaeothermal (AFTA and VR) and compaction (density log-derived porosities) are used to estimate the amounts by which the preserved Lower Jurassic and Oligocene-Miocene successions penetrated by the Mochras borehole in the Cardigan Bay Basin have been more deeply buried prior to exhumation, whilst AFTA and stratigraphic observations are used to constrain the timing of exhumation at this location. The Mochras borehole is located only c. $50 \mathrm{~km}$ to the SW of the deeply eroded EISB, where post-Triassic sediments are largely absent, such that the preserved stratigraphic record cannot be used to constrain the timing and separate the effects of late Mesozoic-Cenozoic exhumation. Many studies have assumed that the main phase of exhumation to affected the EISB and NW Wales began during early Palaeogene times (e.g. Brodie \& White 1994; Cope 1994; Rowley \& White 1998). The preservation of a thick Lower Jurassic (c. $1.3 \mathrm{~km})$ and Cenozoic (c. $0.52 \mathrm{~km})$ sedimentary record at Mochras should provide valuable insights into the exhumation history of the wider region by enabling the effects of Neogene exhumation to be separated from those of earlier events. A more complete analysis of the MesozoicCenozoic burial and exhumation history of the Mochras borehole is presented in Holford et al. (2005a).

A palaeothermal dataset comprising four AFTA samples and 24 VR samples was first used to constrain the thermal history of the Mochras borehole. Of the AFTA samples 
analysed, the most precise thermal history solution was provided by the deepest sample, GC399-13, obtained from a suite of Triassic sandstones (deposited between 220-205 Ma; Woodland 1971) located near the base of the borehole (1910-1931 metres). This AFTA sample yielded a pooled fission-track age (indicating that the apatite grains all come from a single age population; Galbraith \& Laslett 1993) of $108.0 \pm 9.4 \mathrm{Ma}$ (Holford et al. 2005a). The present-day temperature at this depth (c. $55^{\circ} \mathrm{C}$ ) (Holford et al. 2005a) is below the temperature range over which most annealing of fission-tracks occurs $\left(c .60-120^{\circ} \mathrm{C}\right.$; Green et al. 1986), and hence the fission-track age of sample GC399-13 is immediately diagnostic of cooling from maximum palaeotemperatures at some time during the late Mesozoic. In order to extract more detailed thermal history information from an AFTA sample, measured track length distributions and fission-track ages are compared against the track length distributions and fission-track ages predicted for a range of thermal history scenarios, using a kinetic annealing model makes full quantitative allowance for the influence of Chlorine content on annealing rates (e.g. Green et al. 2002). This process is illustrated in Figure 4 for sample GC399-13. The best fit to the measured data is clearly provided by a thermal history solution involving two discrete episodes of heating and cooling. An early Cretaceous episode accounts for the reduction of fission-track age in apatites containing $<0.2 \mathrm{wt} \% \mathrm{Cl}$ and the proportion of short lengths within the overall track length distribution whilst a Cenozoic episode is also required to explain the shortening of the main mode in the track length distribution (Fig. 4). If either of these episodes is omitted this results in predictions that fail to match one or more facets of the basic AFTA parameters (Fig. 4).

A more detailed temperature-time history for sample GC399-13 is shown in Figure 5. Best estimates of maximum palaeotemperature and time of cooling for each AFTA sample analysed in this study have been obtained using maximum likelihood theory similar to the method described by Gallagher (1995). The systematic variation of both the timing of the onset of cooling and the peak palaeotemperature around the best fit values allows the range of conditions for which the modelled parameters are consistent with the measured data within $95 \%$ confidence limits to be defined. Following deposition around $220 \mathrm{Ma}$, sample GC399-13 was heated during burial to a maximum palaeotemperature of $105-110^{\circ} \mathrm{C}$. This compares well with palaeotemperatures estimated from VR samples $\left(102-104^{\circ} \mathrm{C}\right)$ at slightly shallower 
depths (Fig. 6), especially considering a usual precision of $5-10^{\circ} \mathrm{C}$ on VR-derived palaeotemperatures (Duddy et al. 1994). Cooling from this palaeotemperature peak began at some time between 150 and $80 \mathrm{Ma}$. A recent synthesis of all available AFTA data from the Irish Sea basin system and the marginal landmasses has identified a regionally extensive early Cretaceous (120-115 Ma) cooling episode which is interpreted as recording a km-scale exhumation event which is also supported by many geological observations (Holford 2006). The early cooling episode recorded by AFTA data at Mochras is thus attributed to early Cretaceous exhumation. The later palaeothermal episode recorded by GC399-13 involves cooling from a lower palaeotemperature peak of between $70-90^{\circ} \mathrm{C}$ beginning between 50 and $0 \mathrm{Ma}$. The heating prior to this cooling episode most likely occurred during Cenozoic burial, and the fact that Lower Miocene sediments have been identified at Mochras (HerbertSmith 1979) means that this second cooling episode probably began during the postearly Miocene (e.g. <20 Ma). The timing of magmatic activity associated with the British Palaeogene Igneous Province (c. 63-52 Ma; Mussett et al. 1988) is indicated in Figure 6 in order to highlight the fact that this sample does not require any early Paleogene palaeothermal effects in order to explain the measured AFTA parameters. This is a surprising result given the proximity of Mochras to the EISB, which has been highlighted as a focus of both substantial early Palaeogene exhumation and palaeothermal activity (e.g. Green et al. 1997; Rowley \& White 1998; Holford et al. 2005b).

In Figure 6, all available AFTA and VR palaeotemperature constraints for the Mochras borehole have been plotted against depth and assigned to either the early Cretaceous or Neogene cooling episodes identified and discussed above. Some of the VR data from the Lower Jurassic succession are affected by geochemical suppression (Holford et al. 2005a), but palaeotemperatures from the non-suppressed Lower Jurassic VR data are generally consistent with the Cretaceous palaeotemperatures from AFTA (Fig. 6). In combination, the early Cretaceous palaeotemperature constraints from AFTA and VR appear to define a sub-linear profile that is approximately parallel to the present-day geothermal gradient (which has a value of $23.4^{\circ} \mathrm{C} \mathrm{km}^{-1}$ ) (Fig. 6). Fitting a linear profile to the early Cretaceous palaeotemperature provides an estimate of the early Cretaceous palaeogeothermal gradient (Fig. 7a). This has a maximum likelihood value of $21^{\circ} \mathrm{C} \mathrm{km}^{-1}$ (Fig. 7a). The 
extrapolation of this palaeotemperature profiles to an assumed early Cretaceous palaeosurface temperature of $20^{\circ} \mathrm{C}$ (based on palaeoclimatic evidence presented in Yalçin et al. 1997) indicates that the Lower Jurassic succession was more deeply buried by $2.55 \mathrm{~km}$ prior to early Cretaceous exhumation. Assuming that the early Cretaceous palaeogeothermal gradient was equivalent to the present-day gradient reduces the amount of Middle Jurassic-Lower Cretaceous section required to explain the early Cretaceous palaeotemperatures to between 1.94 and $2.49 \mathrm{~km}$ (Fig. 7a). These estimates are in good agreement with the results of Kemp et al. (2005), who on the basis of clay mineral assemblages suggested that the deepest parts of the Lower Jurassic succession at Mochras had been buried to depths of c. $3 \mathrm{~km}$. This estimate was based upon an assumed palaeogeothermal gradient of $30^{\circ} \mathrm{C} \mathrm{km}^{-1}$. Since AFTA and VR data indicate that palaeogeothermal gradients at Mochras were equal to or less than the value of the present-day gradient $\left(\right.$ c. $\left.23.4^{\circ} \mathrm{C} \mathrm{km}^{-1}\right)$, the smectite-illite data of Kemp et al. (2005) can be reinterpreted as supporting burial depths exceeding 3.5 $\mathrm{km}$.

Palaeotemperatures from Cenozoic VR samples, when combined with constraints on Cenozoic palaeotemperatures from the Jurassic AFTA samples, also define a palaeogeothermal gradient which is sub parallel with the present-day geothermal gradient. This Cenozoic palaeogeothermal gradient has a maximum likelihood value of $17^{\circ} \mathrm{C} \mathrm{km}^{-1}$ (Fig. 7b). Extrapolating these palaeotemperature profiles to an assumed palaeosurface temperature of $15^{\circ} \mathrm{C}$ indicates that the preserved Oligocene-Miocene section at Mochras was more deeply buried by $2.15 \mathrm{~km}$ of additional section prior to the second phase of exhumation recorded by AFTA. If the value of the palaeogeothermal gradient was equivalent to that of the present-day geotherm, this implies that between 1.3 and $1.56 \mathrm{~km}$ of additional post-early Miocene sediments were deposited at Mochras prior to exhumation (Fig. 7b).

In order to corroborate these estimates of deeper burial based on palaeotemperature data, the formation density log acquired at Mochras (Woodland 1971) has been used to evaluate the variation of porosity with depth within the preserved sediments. The calculated porosities from the fine grained units within Jurassic and Cenozoic successions have then been compared with Sclater \& Christie's (1980) compaction trend for Central Graben (North Sea) shales; the vertical (i.e. depth) displacement of 
the observed porosities from the normal, unexhumed trend gives a measure of apparent exhumation $\left(E_{\mathrm{A}}\right)$ (i.e. exhumation which is not subsequently reversed by burial) (Hillis 1995; Corcoran \& Doré 2005). The evidence from AFTA and VR data, which indicate that geothermal gradients at Mochras have remained at consistently low values $\left(<23.4^{\circ} \mathrm{C} \mathrm{km}^{-1}\right)$ over time suggests that effects related to thermochemical compaction (which generally occurs at temperatures exceeding $80^{\circ} \mathrm{C}$; Bjørkum et al. 2001) are probably unimportant at Mochras, and hence mechanical compaction during burial is likely to exert the principal control on porosity reduction. Further details of the methodology employed in the analysis of compaction data from Mochras are provided by Holford et al. (2005a).

Densities and calculated porosities for the Mochras borehole are shown in Figure 8. Within the Oligocene-Miocene succession, calculated porosities decrease from c. 30$32 \%$ at depths of around $100 \mathrm{~m}$ to c. $20-22 \%$ at the base of the Oligocene (c. $600 \mathrm{~m}$ ). Comparing these calculated porosities with the Sclater \& Christie (1980) compaction trend for North Sea shales yields apparent exhumation estimates of 1.32-1.48 km for the Oligocene-Miocene succession. In order to determine magnitudes of total exhumation $\left(E_{\mathrm{T}}\right)$ it is necessary to add the amount of post-exhumation burial $\left(B_{\mathrm{E}}\right)$ to $E_{\mathrm{A}}$. Thus, accounting for the $77.47 \mathrm{~m}$ of Quaternary sediments encountered at Mochras, this indicates that the preserved Oligocene-Miocene succession has been more deeply buried by $1.39-1.56 \mathrm{~km}$ prior to exhumation. Compaction data from the Lower Jurassic succession yield estimates of 2.75-3.44 for $E_{\mathrm{A}}$. Correcting for the $601.83 \mathrm{~m}$ of Cenozoic sediments yields $E_{\mathrm{T}}$ estimates of 3.35-4.04 km. The estimates of the amounts by which the Cenozoic and Lower Jurassic successions were more deeply buried prior to exhumation from both compaction and palaeothermal data are compared in Figure 7. For both exhumation episodes the amounts of deeper burial indicated by the compaction data are well within the ranges of values allowed by AFTA and VR. In particular, the estimates of deeper burial prior to the Neogene exhumation episode from the compaction data $(1.39-1.56 \mathrm{~km})$ are in excellent agreement with those from AFTA and VR if it assumed that the palaeogeothermal gradient was equivalent to the present-day gradient (1.3-1.56 km) (Figure 7).

The quantitative constraints on former burial depths from palaeothermal and compaction data, in combination with the preserved stratigraphy encountered by the 
borehole, have been used to reconstruct the post-Triassic burial history of Mochras. Two end-member burial history reconstructions are presented in Figure 9. These burial histories are identical in most respects, with the main difference between them being the amount of burial and exhumation during late Cretaceous-early Palaeogene times. Both histories assume a constant geothermal gradient throughout time $\left(23.4^{\circ} \mathrm{C}\right.$ $\mathrm{km}^{-1}$ ) and incorporate $2.5 \mathrm{~km}$ of additional post-Lower Jurassic sediments which are completely removed during early Cretaceous (120-115 Ma) exhumation. Model 1 incorporates no burial or exhumation during the late Cretaceous-early Palaeogene; on the basis of regional geological evidence (e.g. widespread deposition of Upper Cretaceous Chalk (Ziegler 1990), AFTA results suggesting early Palaeogene exhumation across northern England (Green 2002)) this scenario is unlikely. Model 2 includes $0.8 \mathrm{~km}$ of late Cretaceous burial, with these sediments completely removed by exhumation beginning at $60 \mathrm{Ma}$. Assuming a constant geothermal gradient of $23.4^{\circ} \mathrm{C} \mathrm{km}^{-1}$ throughout the modelled history and an early Palaeogene surface temperature of $20^{\circ} \mathrm{C}, 0.8 \mathrm{~km}$ is the maximum amount of late Cretaceous burial allowed by AFTA sample GC399-13 (Fig. 5). Thermal history modelling of this sample indicates that it cooled from a palaeotemperature peak of between 70 and $90^{\circ} \mathrm{C}$ at some point between 50 and $0 \mathrm{Ma}$ (Fig. 5). This suggests that this sample was not exposed to temperatures in excess of $70^{\circ} \mathrm{C}$ during early Palaeogene times (i.e. before $50 \mathrm{Ma}$ ); under the modelled scenario therefore, $0.8 \mathrm{~km}$ is the maximum amount of late Cretaceous burial/early Palaeogene exhumation that could have occurred at Mochras without affecting the measured AFTA parameters. This figure is much lower than previous estimates of the magnitude of early Palaeogene exhumation across NW Wales and the adjacent EISB, which suggest exhumation of up to $2.5 \mathrm{~km}$ (e.g. Cope 1994; Rowley \& White 1998).

To summarise, the synthesis of palaeothermal and compaction data from the Mochras borehole reveals evidence for two major cycles of burial and exhumation during the Mesozoic-Cenozoic. AFTA, VR and compaction data show that the preserved $1.3 \mathrm{~km}$ thick Lower Jurassic succession has been more deeply buried by up to $2.5 \mathrm{~km}$ prior to Cretaceous exhumation; comparison with regional AFTA results (Holford et al. 2005b; Holford 2006) suggests that this exhumation began during the early Cretaceous (120-115 Ma). Following this major exhumation episode, AFTA data from Mochras allow a maximum of $0.8 \mathrm{~km}$ of late Cretaceous burial/early Palaeogene 
exhumation. This value is much lower than many other estimates of early Paleogene exhumation in the Irish Sea basin system (e.g. Cope 1994; Rowley \& White 1998), and is suggestive of major heterogeneities in early Palaeogene exhumation patterns across this region. Palaeothermal and compaction data show that the main phase of Cenozoic exhumation in this part of the Irish Sea basin system occurred during the Neogene.

The discovery of a c. $520 \mathrm{~m}$ thick Oligocene-Miocene sedimentary succession by the drilling of Mochras in the late 1960's was, at the time, a surprising result (Woodland 1971) because mid-late Cenozoic rocks are rarely preserved in the British Isles (Curry 1992). However, the analysis of the palaeothermal and mechanical properties of the Oligocene-Lower Miocene deposits indicates that they have in fact been more deeply buried by up to $1.5 \mathrm{~km}$ of post-Lower Miocene sediments, which were eroded prior to the deposition of a thin veneer of Quaternary sediments in the CBB. The recognition of this major late Cenozoic episode has profound implications, not only for the relative importance of Palaeogene and Neogene events in the Cenozoic exhumation of the Irish Sea basin system, but also for the mid-late Cenozoic palaeogeography of the Western UKCS. Assessing the cause of the major Neogene exhumation episode in the CBB is difficult; its fill has been penetrated by only one borehole (Mochras), and due to the relative lack of hydrocarbon exploration few seismic reflection data are available for this basin. In contrast, the en echelon SGCB which also contains thick sequences of mid-Cenozoic deposits, has experienced a long history of exploration (e.g. Barr et al. 1981). A number of exploration wells have been drilled in the SGCB, and several parts of the basin benefit from dense 2D seismic reflection coverage. In the next part of this paper, palaeothermal and compaction data are used to constrain the magnitude of Neogene exhumation in the SGCB and seismic reflection data are used to show the important role of compressional deformation as a driving mechanism behind this exhumation.

\section{Neogene exhumation in the St George's Channel Basin}

The SGCB is a NE-SW trending half-graben which is downfaulted along its SE margin against the Palaeozoic Welsh Massif by the Bala-St George's fault system, a major reactivated Caledonian lineament (Barr et al. 1981). The SGCB is one of the 
deepest basins on the UKCS, with approximately $3 \mathrm{~km}$ of undeformed Carboniferous strata overlain by a post-Variscan sedimentary infill which locally exceeds $7 \mathrm{~km}$ (Tappin et al. 1994). Since no wells or boreholes have penetrated the complete succession, the stratigraphy of the basin fill is poorly constrained (Tappin et al. 1994). Individual exploration wells have encountered thick sequences of Triassic, Jurassic and Cenozoic sediments however (Barr et al. 1981; Dobson \& Whittington 1987; Tappin et al. 1994).

Using a combination of seismic reflection, compaction and palaeothermal data Williams et al. (2005) identified three important phases of exhumation which affected the SGCB and its margins during the Cretaceous-Cenozoic. Firstly, up to $2.5 \mathrm{~km}$ of section was removed from the NW and SE margins of the basin during early Cretaceous times. This episode is recorded by seismic reflection data and AFTA results from the Central Irish Sea Basin (Duncan et al. 1998; Green et al. 2001a) and SW Wales (Williams et al. 2005). In contrast to the en echelon CBB, the main depocentre of the SGCB appears to have been unaffected by this episode. One possible explanation for this is that the deep bathymetry which developed within the SGCB during the Jurassic (Turner 1996) meant that uplift during the early Cretaceous was not accompanied by erosion (Williams et al. 2005). Secondly, the SGCB experienced regional exhumation during the late Cretaceous-Palaeogene, responsible for the Jurassic/Palaeogene unconformity recorded on seismic reflection profiles. This event involved a component of NW directed shortening which was responsible for local contractional fault reactivation along the basin margins (Williams et al. 2005). The SGCB experienced a final phase of exhumation during late Cenozoic times, the evidence for which is recorded by the preserved Palaeogene sediments within the basin. Based on comparison with results from Mochras, where the preserved Lower Miocene sediments provide tight constraints on the timing of exhumation, the late Cenozoic exhumation of the SGCB is assigned a Neogene, probably Miocene, timing.

Figure 10 presents a series of structural contour maps for basal and top Triassic, basal Cenozoic and intra-Eocene levels within the basin, based on the interpretation of a $c$. $3000 \mathrm{~km}^{2}$ grid of well-tied 2D seismic reflection data (Williams et al. 2005). There are several lines of evidence for Neogene shortening of the basin from these maps. Structural culminations located along right-stepping jogs on the main NE-trending 
fault systems of the basin (Fig. 10c, d) record their left-lateral reactivation during Neogene compression (Williams et al. 2005). Furthermore, Figures 10c and d show the presence of a broad, NW-trending anticline located within the main depocentre of basin which is confined to the Palaeogene succession; this kind of evidence (i.e. disharmonic folding, thin-skinned deformation) is typical of that used to recognise the compressional shortening of formerly extensional sedimentary basins (Turner \& Williams 2004). In other parts of the basin the Palaeogene and Mesozoic sequences display a significant, consistent structural dip (e.g. Fig. 11) indicating a postPalaeogene timing of deformation. The core of this Neogene fold is penetrated by two exploration wells, 106/24a-2b and 106/24-1. AFTA and VR data from these wells permit the magnitude of exhumation associated with Neogene compressional deformation to be estimated directly.

\section{$106 / 24 a-2 b$}

A palaeotemperature-depth plot for $106 / 24 a-2 b$ is shown in Figure 12a. Corrected BHT data indicate a present-day geothermal gradient of $32^{\circ} \mathrm{C} \mathrm{km}^{-1}$ in this well. The maximum palaeotemperatures experienced by the Oligocene and Jurassic units have been estimated using $22 \mathrm{VR}$ and two AFTA samples. All of these samples have been hotter in the past, and the VR-derived palaeotemperatures are mostly c. $30^{\circ} \mathrm{C}$ higher than the present-day temperatures in the well. The palaeotemperatures from AFTA and VR are in good agreement with each other, and collectively define an approximately linear palaeotemperature profile. The fact that VR-derived palaeotemperatures from both the Oligocene and Jurassic successions shown no significant offset across the top-Jurassic unconformity (Fig. 12a) indicates that maximum palaeotemperatures, and hence maximum burial depths within this well, were attained following the deposition of the preserved Cenozoic succession. Assuming that the palaeogeothermal gradient prior to exhumation had a similar value to the present-day gradient $\left(32^{\circ} \mathrm{C} \mathrm{km}^{-1}\right)$ indicates that the preserved section was more deeply buried by between 0.8 and $1 \mathrm{~km}$ prior to Neogene exhumation (Fig. 12b). This is in excellent agreement with the amount of deeper burial at this location estimated from compaction data; based on the analysis of anomalously high sonic velocities within the Upper Triassic Mercia Mudstone Group succession encountered by this well, Williams et al. (2005) estimated that the pre-Jurassic units had been more 
deeply buried by c. $1 \mathrm{~km}$. Although palaeothermal and compaction data provide no direct evidence for any significant late Cretaceous-early Palaeogene exhumation, appreciable exhumation would be allowed at this time provided that the thickness of eroded section did not exceed that accumulated during subsequent burial (Fig. 12c).

\section{$106 / 24-1$}

Similar results regarding Neogene exhumation magnitudes are provided by palaeothermal data from 106/24-1, which also penetrated the crest of the Neogene inversion anticline (Fig. 10). Three bottom-hole temperature measurements for this well define a linear present-day geothermal gradient with a value of $29.4^{\circ} \mathrm{C} \mathrm{km}^{-1}$ for this well, which encountered c. $0.6 \mathrm{~km}$ of Eocene-Oligocene sediments similar to those recovered from Mochras which rest unconformably upon almost $2 \mathrm{~km}$ of UpperMiddle Jurassic mudstones (Tappin et al. 1994). VR data from this well define a dogleg profile, with VR-derived palaeotemperatures within the Palaeogene and uppermost Jurassic successions around $20^{\circ} \mathrm{C}$ higher than present-day temperatures (Fig. 13a). Below depths of c. $1.5 \mathrm{~km}$ however, the palaeotemperature estimates from VR converge with the present-day temperature profile. The lower VR values within the overall trend have been interpreted to have been affected by geochemical suppression, resulting in anomalously low reflectances (Carr 2000). Suppression commonly affects hydrogen-rich marine facies such as the Lower Jurassic mudstones which are widely distributed across the British Isles (Scotchman 2001), including some of the Lower Jurassic VR samples from Mochras (Holford et al. 2005a).

Thermal history analysis of a single Bathonian-aged AFTA sample obtained from this well from a depth of $2408 \mathrm{~m}$ indicated that this sample had cooled from a maximum palaeotemperature of between 75 and $90^{\circ} \mathrm{C}$ at some time between its deposition and the present-day. Assuming that the palaeotemperatures from the vitrinite samples at depths $>1.5 \mathrm{~km}$ are erroneous due to suppression, combining the shallower VR data with the palaeotemperature constraints from AFTA enables the determination of a palaeogeothermal gradient related to Palaeogene/post-Palaeogene burial-related heating. As in the case of $106 / 24 a-2 b$, palaeotemperatures from VR show no significant offset across the Palaeogene/Jurassic unconformity, suggesting that maximum burial at this location was also occurred during the Cenozoic (Fig. 13a, c). 
Assuming the value of the palaeogeothermal gradient to be equivalent to the presentday gradient reduces the amount of additional Palaeogene-Neogene section required to explain the palaeotemperature constraints to between 0.65 and $0.9 \mathrm{~km}$. This estimate is similar to that obtained for the nearby $106 / 24 \mathrm{a}-2 \mathrm{~b}$ well $(0.8$ to $1.0 \mathrm{~km})$, and considered together these results provide tight, direct constraints on the magnitude of Neogene exhumation caused by compressional deformation in the SGCB.

\section{$106 / 28-1$}

Elsewhere in the basin, palaeothermal data record similar magnitudes of Neogene exhumation. Exploration well 106/28-1 drilled the footwall of the inverted St George's Fault, on the SE margin of the basin. It penetrated a thick Triassic succession overlain by a thin Lower Jurassic sequence and c. $0.7 \mathrm{~km}$ of EoceneOligocene sediments (Tappin et al. 1994). Seventeen VR samples encompass the Palaeogene and Lower Jurassic sequences, whilst a single AFTA sample from the Triassic succession provides useful constraints on palaeotemperatures in the deeper parts of the section, where VR data are unavailable due to the terrestrial origin of the Triassic succession (Fig. 14a). VR-derived palaeotemperatures define an approximately linear palaeogeothermal gradient which is similar in profile and value of the present-day geothermal gradient $\left(34.7^{\circ} \mathrm{C} \mathrm{km}^{-1}\right)$ (Fig. 14a). As with other examples discussed in this paper, the consistency of palaeotemperature data either side of the Palaeogene/Lower Jurassic unconformity attests to maximum burial of the preserved Mesozoic and Cenozoic units in the SGCB occurring prior to Neogene exhumation. Thermal history modelling of AFTA parameters from the Triassic sample reveals evidence for one palaeothermal episode, involving cooling from a palaeotemperature of $90-110^{\circ} \mathrm{C}$ at some point following deposition. The range of palaeotemperatures indicated by AFTA are in good agreement with a palaeotemperature profile fitted to the palaeothermal constraints from VR (Fig. 14a), which strongly suggests that the AFTA and VR data record the same burial episode. Assuming a palaeogeothermal gradient with a value equivalent to that of the presentday geotherm for this well indicates that the preserved section in this well was more deeply buried by an additional 0.65 to $0.9 \mathrm{~km}$ of Palaeogene-Neogene section which was subsequently eroded (Fig. 14b). This estimate is in broad agreement with the amount of deeper burial of the Triassic succession inferred from Mercia Mudstone 
Group sonic velocity data (c. $1.24 \mathrm{~km}$; Williams et al. 2005) (which in itself, falls well within the range of values for deeper burial allowed by palaeothermal data (Fig. $14 b))$.

Estimates of the amount of deeper burial prior to Neogene exhumation for all wells and boreholes from the southern Irish Sea which have been analysed for this study are shown in Figure 15. A striking feature revealed in this diagram is the consistency of the exhumation estimates which have been obtained for individual wells using separate techniques - palaeothermal data, compaction data (using density and sonic velocity logs) and also erosion estimates based on seismic reflection data (Fig. 15). This overall consistency serves to confirm the magnitude of Neogene exhumation in this region and also validates the reliability of the separate approaches which have been employed to calculate exhumation. When considering these estimates, it should be noted that since most of the wells in the SGCB are drilled on inversion structures (e.g. 107/16-1; Fig. 16) where exhumation magnitudes are likely to be highest, these estimates should be regarded as upper limits on the total amount of Neogene exhumation in this basin. In detail, the actual patterns of exhumation within the basin are likely to be more heterogeneous than the results presented here suggest. Compressional shortening in sedimentary basins is characteristically non-uniform (Turner \& Williams 2004). This non-uniformity is expressed on a variety of scales, from the contractional reactivation of a single extensional fault (e.g. Williams et al. 1989) and the selective reactivation of faults within a synthetic fault array (e.g. Sibson 1995) to the differential shortening of the crust and lithosphere (e.g. Nielsen \& Hansen 2000). A major consequence of non-uniform shortening is that exhumation patterns are typically heterogeneous (cf. Argent et al. 2002). Following on from this point, Williams et al. (2005) have suggested that Neogene exhumation in the SGCB is likely to have been highly variable due to the noncoaxial strain history during the inversion episode.

\section{Discussion - implications for the timing and causes of Cenozoic exhumation in the Irish Sea}

AFTA, VR and compaction data from boreholes and wells in the southern Irish Sea show that the preserved Cenozoic sediments in these basins were more deeply buried 
by up to $1.5 \mathrm{~km}$ prior to Neogene exhumation. Moreover, seismic reflection data provide abundant evidence for the compressional shortening of the preserved Cenozoic strata, indicating that this was the principal cause of this exhumation episode. The amount of bulk Cenozoic shortening in the southern Irish Sea has been estimated following the line-length restoration of the uppermost Lower Jurassic marker horizon on a cross section which extends from the SGCB, through the St Tudwal's Arch to the Central Irish Sea Basin (Fig. 17). The Lower Jurassic succession in this cross section exhibits pronounced thickening towards the uplifted structural culmination of St Tudwal's Arch (offshore Llŷn Peninsula), with bulk shortening estimated at c. $15 \%$ (Ware \& Turner 2002). The uniform shortening of a hypothetical column of continental lithosphere $125 \mathrm{~km}$ in thickness (crust $=30 \mathrm{~km}$, crustal density $=2.8 \mathrm{~g} \mathrm{~cm}^{-3}$, mantle density $=3.3 \mathrm{~g} \mathrm{~cm}^{-3}$ ) by $15 \%$ should result in 1.5 $\mathrm{km}$ of exhumation (following the isostatic calculations of Brodie \& White 1995), similar to the upper limit of Neogene exhumation indicated by palaeothermal and compaction data from the southern Irish Sea.

To the northwest of this cross section, the general absence of typical tectonic inversion structures (e.g. contractionally reactivated normal faults) in the East Irish Sea has led some workers to rule out compressional shortening as a driving mechanism of exhumation in this basin (Brodie \& White 1995). However, as argued by Ware \& Turner (2002) and Williams et al. (2005), given that inversion geometries are most pronounced in the shallow parts of compressionally shortened basins where reverse fault displacements are greatest, the evidence for inversion may be largely obliterated in deeply exhumed basins such as the East Irish Sea. Moreover, AFTA data from the East Irish Sea provides evidence for up to $1 \mathrm{~km}$ of exhumation which began between 30 and $10 \mathrm{Ma}$ (Holford 2006), consistent with the timing of compressional shortening and exhumation in the southern Irish Sea. It is probable that a substantial proportion of exhumation in the East Irish Sea which has previously been attributed to early Palaeogene events actually occurred during the Neogene.

In the southern Irish Sea it has not been possible to directly constrain the magnitude of early Palaeogene exhumation. In the SGCB maximum burial depths of the preserved sedimentary succession were attained during the mid-late Cenozoic, whilst AFTA data from Mochras reveal no evidence for elevated palaeotemperatures during 
the early Palaeogene, and hence do not require significant exhumation at this time. The fact that AFTA data from several other parts of the Irish Sea basins and their margins indicate substantial early Palaeogene exhumation e.g. up to $2 \mathrm{~km}$ in the Central Irish Sea Basin (Green et al. 2001a) and up to $1.5 \mathrm{~km}$ in northern England (Green 2002) suggests that early Palaeogene exhumation patterns were markedly heterogeneous.

Early Palaeogene exhumation in the British Isles is commonly attributed to processes associated with mantle plume activity (e.g. underplating, thermal uplift) (Brodie \& White 1994; White \& Lovell 1997; Jones et al. 2002). Theoretical modelling of such processes predicts the occurrences of broad, epeirogenic regional uplift over horizontal distances of hundreds to thousands of kilometres (e.g. White \& McKenzie 1989). Epeirogenic uplift processes should result in smooth, progressive variations in exhumation patterns (Argent et al. 2002). The observed early Palaeogene exhumation patterns in the Irish Sea would appear to be inconsistent with a sole, epeirogenic driving mechanism, although they could be explained in terms of compressional shortening superimposed upon epeirogenic uplift (Williams et al. 2005). Given that the Irish Sea is thought to be a locus of Iceland Plume-related magmatic underplating during the early Palaeogene however, the observation of no substantial coeval exhumation at Mochras carries important implications for the role of the Iceland Plume in Palaeogene vertical tectonic motions across the NW European continental shelf.

The synthesis of an extensive AFTA dataset incorporating samples from the all parts of the Irish Sea basin system reported in Holford (2006) reveals evidence for a regional exhumation-related late Cenozoic cooling episode which began between 25 and $15 \mathrm{Ma}$ (Figure 18). The additional stratigraphic constraints from Mochras, where sediments of Early Miocene age are preserved (Herbert-Smith 1979) help refine the timing of this event to beginning between ?20 and $15 \mathrm{Ma}$ (Figure 18). This dataset includes samples from the onshore landmasses which surround the mostly submerged Irish Sea basins (e.g. northern England, Ireland and Wales). It is notable that the Neogene exhumation episode observed within the offshore sedimentary basins is also recorded by AFTA data from the apparently stable basin margins. For example, AFTA data from across onshore Ireland reveal evidence for regional cooling which 
began between 25 and $15 \mathrm{Ma}$ and is also interpreted in terms of km-scale exhumation (Green et al. 2000). The general absence of Mesozoic-Cenozoic sediments and lack of seismic reflection data from these non-basinal regions makes it difficult to detect the possible contribution of compressional deformation to this exhumation, although it is noted that both Bevins et al. (1996) and Cunningham et al. (2004) have reported evidence for Cenozoic tectonic deformation (i.e. fault movement) in North Wales and SE Ireland respectively, the kinematics of which are similar to those of Neogene compressional and transpressional shortening in the SGCB (Turner 1997; Williams et al. 2005) and Central Irish Sea Basin (Izatt et al. 2001). One possible model which can account for the Neogene exhumation of both the Irish Sea basins and their margins solely in terms of compressional shortening is that of Hillis (1992). Hillis (1992) attempted to reconcile the observation of localised compressional deformation superimposed upon more regional Cenozoic exhumation across the British Isles by invoking a two-layer (i.e. depth-dependent) model of lithospheric compression, analogous to more familiar two-layer models of lithospheric extension (e.g. Kusznir \& Ziegler 1992; Davis \& Kusznir 2004). Under this scenario, compressional shortening and thickening in the lower crust and lithospheric mantle may be laterally displaced from, or occur across a broader wavelength than the compressional shortening in the brittle upper crust, thereby explains the regional component of exhumation which extends beyond the inverted sedimentary basins (Hillis 1992). Additionally or alternatively, the Neogene compressional shortening observed in the southern Irish Sea basins may be superimposed on the enigmatic regional Neogene uplift event which has been reported from many parts of the Atlantic margins (e.g. Doré et al. 1999; Thomson et al. 1999; Japsen \& Chalmers 2000; Japsen et al. 2005; Bonow et al. 2006).

Outwith the Irish Sea, Neogene compressional shortening has been identified within many sedimentary basins around the British Isles, including the southern North Sea (Badley et al. 1989), the Wessex Basin (Chadwick \& Evans 2005) and in MesozoicCenozoic basins along the UK Atlantic margin (Stoker et al. 2005). The timing of these episodes of compressional deformation is very similar to that identified by this study. Along the UK Atlantic margin for example, compressional deformation at c. 16 Ma contributed to the development of a widespread intra-Miocene unconformity (Stoker et al. 2005). 
There is strong evidence for substantial coeval exhumation across parts of the Atlantic margin from AFTA data. For example, AFTA and VR data from the 204/19-1 well located on the Westray Ridge in the Faeroe-Shetland Basin indicate that between 0.63 and $0.9 \mathrm{~km}$ of Eocene-Oligocene strata were eroded prior to late Miocene sedimentation (Parnell et al. 2005). The correlation between the timing of the compressional deformation and exhumation of the UK Atlantic margin and the Irish Sea basin system (e.g. Figure 18) is an important observation, which implies that the forces which caused the deformation along the margin may also have been responsible for the compressional deformation and $\mathrm{km}$-scale exhumation of an intraplate sedimentary basin located at least $1000 \mathrm{~km}$ from the most proximal plate boundary or margin.

The source of the compressional stress responsible for the deformation observed in sedimentary basins around the British Isles during the Neogene has mostly been attributed to either late Alpine lithospheric shortening (e.g. Ziegler et al. 1995, 1998; Blundell 2002) or Atlantic seafloor spreading and associated ridge-push forces (e.g. Boldreel \& Andersen 1993, 1998; Lundin \& Doré 2002; Stoker et al. 2005). Studies of the origins of the present-day regional stress fields in the interiors of both the European (Gölke \& Coblentz 1996) and Indo-Australasian plates (Reynolds et al. 2002) using finite element analyses have shown that the state of stress at any point within the plate is a function of the net torques of all the plate boundary forces (Reynolds et al. 2002). This suggests that the Neogene compressional deformation in the Irish Sea is a function of both Atlantic ridge-push forces and Alpine lithospheric shortening. In this respect, it is worth drawing attention to Figure 18 which shows that the Neogene compression-driven exhumation of the Irish Sea basins was coeval with both the separation of the Jan Mayen microcontinent from Greenland and the late Alpine phase of collisional shortening in central and western Europe (cf. Stoker et al. 2005). These observations show that plate boundary deformation events play an important role in the generation of vertical tectonic motions across continental interiors, and are capable of causing the $\mathrm{km}$-scale exhumation of intraplate regions. 


\section{Conclusions}

- The presence of up to $1.5 \mathrm{~km}$ of preserved Cenozoic sediments within the southern Irish Sea has enabled the effects of late Cenozoic exhumation within the Irish Sea basin system to be separated from those of earlier events. Palaeothermal (AFTA and VR) and compaction data have been used to calculate Neogene exhumation magnitudes whilst seismic reflection data have been used to constrain the origins of the exhumation.

- AFTA, VR and compaction (density-log derived porosity) data have been used to determine the thermal and exhumation histories of the Mochras borehole which penetrated the sedimentary fill of the Cardigan Bay Basin. Palaeothermal and compaction data reveal that the preserved Lower Jurassic succession within this basin was more deeply buried by c. $2.5 \mathrm{~km}$ of additional section prior to early Cretaceous exhumation, whilst the preserved late Oligocene-early Miocene succession was more deeply buried by an additional c. $1.5 \mathrm{~km}$ of Miocene sediments prior to Neogene exhumation. AFTA data from this borehole provide no evidence for early Palaeogene cooling, and hence exhumation at this location. This is a surprising result, since many previous studies have described the Irish Sea basin system as the locus of early Palaeogene exhumation across the British Isles.

- Palaeothermal and compaction data from exploration wells in the St George's Channel Basin show that the preserved Eocene-Oligocene rocks in this basin were more deeply buried by up to $1 \mathrm{~km}$ of additional section prior to Neogene exhumation. Maximum burial depths of the Mesozoic succession in this basin were also attained prior to Neogene exhumation, and hence it is not possible to directly constrain magnitudes of early Cretaceous and early Palaeogene exhumation.

- These results raise important questions regarding the driving mechanisms of early Palaeogene exhumation, which is commonly attributed to epeirogenic, plumerelated processes such as magmatic underplating.

- Seismic reflection data show that compressional deformation was the principal mechanism driving Neogene exhumation in the St George's Channel Basin. 
- The synthesis of a regional AFTA dataset constrains the onset of late Cenozoic exhumation in the Irish Sea basin system to beginning between 25 and $15 \mathrm{Ma}$. The preserved Lower Miocene sediments at Mochras permit the constraints on the timing of this episode to be refined further to beginning between ?20 and 15 Ma.

- The timing of compressionally-driven exhumation in the southern Irish Sea is coeval with intra-Miocene compression and exhumation observed along the UK Atlantic margin. This suggests that the forces responsible for the deformation of the margin were also responsible for the shortening and exhumation of an intraplate sedimentary basin system located $>1000 \mathrm{~km}$ from the most proximal plate boundary.

- Finite element modelling of the origins of stress fields in continental interiors suggests that the state of stress at any point within the plate is a function of the net torques of all the plate boundary forces. The Neogene compression in the Irish Sea is thus probably a function of both Atlantic ridge-push forces and late Alpine lithospheric shortening.

- The results presented in this paper demonstrate that compressional deformation has played an important contributing role to the Neogene exhumation of the NW European continental shelf.

\section{Acknowledgments}

This paper has benefited from discussions with R. Hillis, P. Japsen, A. Doré and J. Underhill. Some of the results reported here formed part of SPH's $\mathrm{PhD}$ research at the University of Birmingham, supported by a NERC-CASE studentship with the British Geological Survey (NER/S/A/2001/05890). Burlington Resources Inc, ChevronTexaco, Exxon Mobil, Shell/Enterprise and Veba Oil \& Gas UK are acknowledged for provision of data, whilst Seismic Micro-Technology are thanked for free provision of their Kingdom Suite seismic interpretation software. GAW and DRT publish with the permission of the Executive Director, British Geological Survey (NERC). The British Geological Survey is also thanked for providing access and permission to sample the Mochras core. 


\section{References}

Al-Kindi, S., White, N., Sinha, M., England, R. \& Tiley, R. 2003. Crustal trace of a hot convective sheet. Geology, 31, 207-210.

Argent, J.D., Stewart, S.A., Green, P.F. \& Underhill, J.R. 2002. Heterogeneous exhumation in the Inner Moray Firth, UK North Sea: constraints from new AFTA ${ }^{\circledR}$ and seismic data. Journal of the Geological Society, London, 159, 715-729.

Badley, M.E., Price, J.D. \& Backshall, L.C. 1989. Inversion, reactivated faults and related structures: seismic examples from the southern North Sea. In: Cooper, M.A. \& Williams, G.D. (eds) Inversion Tectonics. Geological Society, London, Special Publications, 44, 201219.

Barr, K.W., Colter, V.S. \& Young, R. 1981. The Geology of the Cardigan Bay-St Georges's Channel Basin. In: Illing, L.V. \& Hobson, G.D. (eds) Petroleum Geology of the Continental Shelf of North-West Europe. Heyden, London, 432-444.

Bevins, R.E., Horak, J.M., Evans, A.D. \& Morgan, R. 1996. Palaeogene dyke swarm, NW Wales: evidence for sinistral fault movement. Journal of the Geological Society, London, 153, 177-181.

Bjørkum, P.A., Walderhaug, O. \& Nadeau, P.H. 2001. Thermally driven porosity reduction: impact on basin subsidence. In: Shannon, P.M., Haughton, P.D.W. \& Corcoran, D.V. (eds) The Petroleum Exploration of Ireland's Offshore Basins. Geological Society, London, Special Publications, 188, 385-392.

Blundell, D.J. 2002. Cenozoic inversion and uplift of southern Britain. In: Doré, A.G., Cartwright, J.A., Stoker, M.S., Turner, J.P. \& White, N. (eds) Exhumation of the North Atlantic Margin: Timing, Mechanisms and Implications for Petroleum Exploration. Geological Society, London, Special Publications, 196, 85-101.

Boldreel, L.O. \& Andersen, M.S. 1993. Late Palaeocene to Miocene compression in the Faeroe-Rockall area. In: Parker, J.R. (ed.) Petroleum Geology of Northwest Europe: Proceedings of the 4th Conference. Geological Society, London, 1025-1034. 
Boldreel, L.O. \& Andersen, M.S. 1998. Tertiary compressional structures on the FaroeRockall Plateau in relation to northeast Atlantic ridge-push and Alpine foreland stresses. Tectonophysics, 300, 13-28.

Bonow, J.M., Lidmar-Bergström, K \& Japsen, P. 2006. Palaeosurfaces in central West Greenland as reference for identification of tectonic movements and estimation of erosion. Global and Planetary Change.

Bray, R., Green, P.F. \& Duddy, I.R. 1992. Thermal history reconstruction in sedimentary basins using apatite fission track analysis and vitrinite reflectance data: a case study from the east Midlands of England and the Southern North Sea. In: Hardman, R.F.P. (ed.) Exploration Britain: Into the Next Decade. Geological Society, London, Special Publications, 67, 3-25.

Brodie, J. \& White, N. 1994. Sedimentary basin inversion caused by igneous underplating. Geology, 22, 147-150.

Brodie, J. \& White, N. 1995. The link between sedimentary basin inversion and igneous underplating. In: Buchanan, J.G. \& Buchanan, P.G. (eds) Basin Inversion. Geological Society, London, Special Publication, 88, 21-38.

Carr, A.D. 2000. Suppression and retardation of vitrinite reflectance, part 1. Formation and significance for hydrocarbon generation. Journal of Petroleum Geology, 23, 313-343.

Chadwick, R.A. \& Evans, D.J. 2005. A seismic atlas of southern Britain - images of subsurface structure. British Geological Survey, Occasional Publication No. 7.

Chadwick, R.A., Kirby, G.A. \& Baily, H.E. 1994. The post-Triassic structural evolution of north-west England and adjacent parts of the East Irish Sea. Proceedings of the Yorkshire Geological Society, 50, 91-102.

Cloetingh, S., Gradstein, F.M., Kooi, H., Grant, A.C. \& Kaminski, M. 1990. Plate reorganization - a cause of rapid late Neogene subsidence and sedimentation around the North Atlantic? Journal of the Geological Society, London, 147, 495-506.

Cope, J.C.W. 1994. A latest Cretaceous hotspot and the southeasterly tilt of Britain. Journal of Geological Society, London, 151, 905-908. 
Corcoran, D.V. \& Doré, A.G. 2005. A review of techniques for the estimation of magnitude and timing of exhumation in offshore basins. Earth-Science Reviews, 72, 129-168.

Coward, M.P. 1995. Structural and tectonic setting of the Permo-Triassic basins of northwest Europe. In: Boldy, S.A.R. (ed.) Permian and Triassic Rifting in Northwest Europe. Geological Society, London, Special Publications, 91, 7-39.

Cunningham, M.J.M., Phillips, W.E.A. \& Densmore, A.L. 2004. Evidence for Cenozoic tectonic deformation in SE Ireland and near offshore. Tectonics, 23, 6002, doi:10.1029/2003TC001597.

Curry, D. 1992. Tertiary. In: Duff, P.McL.D. \& Smith, A.J. (eds) Geology of England and Wales. Geological Society, London, 389-411.

Davis, M. \& Kusznir, N.J. 2004. Depth-dependent lithospheric stretching at rifted continental margins. In: Karner, G.D. (ed.) Proceedings of NSF Rifted Margins Theoretical Institute. Columbia University Press, 92-136.

Dobson, M.R. \& Whittington, R.J. 1987. The geology of Cardigan Bay. Proceedings of the Geologists’ Association, 98, 331-353.

Doré, A.G., Lundin, E.R., Jensen, L.N., Birkeland, Ø., Eliassen, P.E. \& Filcher, C. 1999. Principal tectonic events in the evolution of the northwest European Atlantic margin. In: Fleet, A.J. \& Boldy, S.A.R. (eds) Petroleum Geology of Northwest Europe: Proceedings of the 5th Conference, 41-61.

Doré, A.G., Cartwright, J.A., Stoker, M.S., Turner, J.P. \& White, N. 2002a. Exhumation of the North Atlantic margin: introduction and background. In: Doré, A.G., Cartwright, J.A., Stoker, M.S., Turner, J.P. \& White, N. (eds) Exhumation of the North Atlantic Margin: Timing, Mechanisms and Implications for Petroleum Exploration. Geological Society, London, Special Publications, 196, 1-12.

Doré, A.G., Corcoran, D.V. \& Scotchman, I.C. 2002b. Prediction of the hydrocarbon system in exhumed basins, and application to the NW European margin. In: Doré, A.G., Cartwright, J.A., Stoker, M.S., Turner, J.P. \& White, N. (eds) Exhumation of the North Atlantic Margin: Timing, Mechanisms and Implications for Petroleum Exploration. Geological Society, London, Special Publications, 196, 401-429. 
Duddy, I.R., Green, P.F., Bray, R.J. \& Hegarty, K.A. 1994. Recognition of the thermal effects of fluid flow in sedimentary basins. In: Parnell, J. (ed.) Geofluids: Origin, Migration and Evolution of Fluids in Sedimentary Basins. Geological Society, London, Special Publications, 78, 325-345.

Duncan, W.I., Green, P.F. \& Duddy, I.R. 1998. Source rock burial history and seal effectiveness: key facets to understanding hydrocarbon exploration potential in the East and Central Irish Sea Basins. AAPG Bulletin, 82, 1401-1415.

Galbraith, R.F. \& Laslett, G.M. 1993. Statistical methods for mixed fission track ages. Nuclear Tracks, 21, 459-470.

Gallagher, K. 1995. Evolving temperature histories from apatite fission-track data. Earth and Planetary Science Letters, 136, 421-435.

Giles, M.R., Indrelid, S.L. \& James, D.M.D. 1998. Compaction - the great unknown in basin modelling. In: Düppenbecker, S.J. \& Iliffe, J.E. (eds) Basin Modelling: practice and Progress. Geological Society, London, Special Publications, 141, 15-43.

Gölke, M. \& Coblentz, D. 1996. Origins of the European regional stress field. Tectonophysics, 266, 11-24.

Gradstein, F.M., Ogg, J.G. \& Smith, A.G. 2004. A Geologic Time Scale 2004. Cambridge University Press, Cambridge.

Green, P.F. 2002. Early Tertiary palaeo-thermal effects in Northern England: reconciling results from apatite fission track analysis with geological evidence. Tectonophysics, 349, 131 144.

Green, P.F. 2005. Burial and exhumation histories of Carboniferous rocks of the Southern North Sea and onshore UK, with particular emphasis on post-Carboniferous events. In: Collinson, J.D., Evans, D.J., Holliday, D.W. \& Jones, N.S. (eds) Carboniferous Hydrocarbon Resources: the Southern North Sea and Surrounding Areas. Yorkshire Geological Society Occasional Publication Series, 7, 25-34.

Green, P.F., Duddy, I.R. \& Bray, R.J. 1997. Variation in thermal history styles around the Irish Sea and adjacent areas: implications for hydrocarbon occurrence and tectonic evolution. 
In: Meadows, N.S., Trueblood, S.P., Hardman, M. \& Cowan, G. (eds) Petroleum Geology of the Irish Sea and Adjacent Areas. Geological Society, London, Special Publications, 124, 73 93.

Green, P.F., Duddy, I.R., Bray, R.J., Duncan, W.I. \& Corcoran, D.V. 2001a. The influence of thermal history on hydrocarbon prospectivity in the Central Irish Sea Basin. In Shannon, P.M., Haughton, P.D.W. \& Corcoran, D.V. (eds) The Petroleum Exploration of Ireland's Offshore Basins. Geological Society, London, Special Publications, 188, 171-188.

Green, P.F., Duddy, I.R. \& Hegarty, K.A. 2002. Quantifying exhumation in sedimentary basins of the UK from apatite fission track analysis and vitrinite reflectance data: precision, accuracy and latest results. In: Doré, A.G., Cartwright, J.A., Stoker, M.S., Turner, J.P. \& White, N. (eds) Exhumation of the North Atlantic Margin: Timing, Mechanisms and Implications for Petroleum Exploration. Geological Society, London, Special Publications, 196, 331-354.

Green, P.F., Duddy, I.R., Gleadow, A.J.R., Tingate, P.R. \& Laslett, G.M. 1986. Thermal annealing of fission tracks in apatite 1. A qualitative description. Chemical Geology, 59, $237-$ 253.

Green, P.F., Duddy, I.R. \& Hegarty, K.A. 2005. Comment on compositional and structural control on fission track annealing in apatite. Chemical Geology, 214, 351-358.

Green, P.F., Duddy, I.R., Hegarty, K.A., Bray, R.J., Sevastapulo, G.D., Clayton, G. \& Johnston, D. 2000. The post-Carboniferous evolution of Ireland: Evidence from Thermal History Reconstruction. Proceedings of the Geologists’ Association, 111, 307-320.

Green, P.F., Thomson, K. \& Hudson, J.D. 2001b. Recognising tectonic events in undeformed regions: contrasting results from the Midland Platform and East Midlands Shelf, Central England. Journal of the Geological Society, London, 158, 59-73.

Hallam A. 1992. Jurassic. In: Duff, P.McL.D. \& Smith, A.J. (eds) Geology of England and Wales. Geological Society, London, 325-354.

Herbert-Smith, M. 1979. The age of the Tertiary deposits of the Llanbedr (Mochras Farm) borehole as determined from palynological studies. Report of the Institute of Geological Sciences, No. 78/24, 15-29. 
Hillis, R.R. 1991. Chalk porosity and Tertiary uplift, Western Approaches Trough, SW UK and NW French continental shelves. Journal of the Geological Society, London, 148, 669679.

Hillis, R.R. 1992. A two-layer lithospheric compressional model for the Tertiary uplift of the southern United Kingdom. Geophysical Research Letters, 19, 573-576.

Hillis, R.R. 1995. Regional Tertiary exhumation in and around the United Kingdom. In: Buchanan, J.G. \& Buchanan, P.G. (eds) Basin Inversion. Geological Society, London, Special Publications, 88, 167-190.

Holford, S.P. 2006. The Mesozoic-Cenozoic exhumation history of the Irish Sea basin system, western UK. Ph.D. Thesis, University of Birmingham, UK.

Holford, S.P., Green, P.F. \& Turner, J.P. 2005a. Palaeothermal and compaction studies in the Mochras borehole (NW Wales) reveal early Cretaceous and Neogene exhumation and argue against regional Palaeogene uplift in the southern Irish Sea. Journal of the Geological Society, London, 162, 829-840.

Holford, S.P., Turner, J.P. \& Green, P.F. 2005b. Reconstructing the Mesozoic-Cenozoic exhumation history of the Irish Sea basin system using apatite fission-track analysis and vitrinite reflectance data. In: Doré, A.G. \& Vining, B. (eds) North West Europe and Global Perspectives: Proceedings of the 6th Petroleum Geology Conference. Geological Society, London, 1095-1108.

Izatt, C., Mairngarm, S. \& Racey, A. 2001. Fault distribution and timing in the Central Irish Sea Basin. In Shannon, P.M., Haughton, P.D.W. \& Corcoran, D. (eds) The Petroleum Exploration of Ireland's Offshore Basins. Geological Society, London, Special Publications, 188, 155-169.

Jackson, D.I. \& Mulholland, P. 1993. Tectonic and stratigraphic aspects of the East Irish Sea Basin and adjacent areas: contrasts in their post-Carboniferous structural styles. In: Parker, J.R. (ed.) Petroleum Geology of Northwest Europe: Proceedings of the $4^{\text {th }}$ Conference. Geological Society, London, 791-808. 
Jackson, D.I., Jackson, A.A., Evans, D., Wingfield, R.T.R., Barnes, R.P. \& Arthur, M.J. 1995. United Kingdom offshore regional report: The geology of the Irish Sea. London: HMSO for the British Geological Survey.

Japsen, P. 1997. Regional Neogene exhumation of Britain and the Western North Sea. Journal of the Geological Society, London, 154, 239-247.

Japsen, P. 2000. Investigation of multi-phase erosion using reconstructed shale trends based on sonic data, Sole Pit axis, North Sea. Global and Planetary Change, 24, 189-210.

Japsen, P., Bidstrup, T. \& Lidmar-Bergstrom, K. 2002. Neogene uplift and erosion of southern Scandinavia induced by the rise of the South Swedish Dome. In: Doré, A.G., Cartwright, J.A., Stoker, M.S., Turner, J.P. \& White, N. (eds) Exhumation of the North Atlantic Margin: Timing, Mechanisms and Implications for Petroleum Exploration. Geological Society, London, Special Publications, 196, 183-207.

Japsen, P., Bonow, J.M., Green, P.F., Chalmers, J.A. \& Lidmar-Bergstrom, K. In press. Elevated, passive continental margins: Long-term highs or Neogene uplifts? New evidence from West Greenland. Earth \& Planetary Science Letters.

Japsen, P. \& Chalmers, J.A. 2000. Neogene uplift and tectonics around the North Atlantic: overview. Global and Planetary Change, 24, 189-210.

Japsen, P., Green, P.F. \& Chalmers, J.A. 2005. Separation of Palaeogene and Neogene uplift on Nuussuaq, West Greenland. Journal of the Geological Society, London, 162, 299-314.

Jones, S.M., White, N., Clarke, B.J., Rowley, E. \& Gallagher, K. 2002. Present and past influence of the Iceland Plume on sedimentation. In: Doré, A.G., Cartwright, J.A., Stoker, M.S., Turner, J.P. \& White, N. (eds) Exhumation of the North Atlantic Margin: Timing, Mechanisms and Implications for Petroleum Exploration. Geological Society, London, Special Publications, 196, 13-25.

Kemp, S.J., Merriman, R.J. \& Bouch, J.E. 2005. Clay mineral reaction progress - the maturity and burial history of the Lias Group of England and Wales. Clay Minerals, 40, 43-61. 
Kusznir, N.J. \& Ziegler, P.A. 1992. The mechanics of continental extension and sedimentary basin formation: a simple-shear/pure-shear flexural cantilever model. Tectonophysics, 215, 117-131.

Lewis, C.L.E., Green, P.F., Carter, A. \& Hurford, A.J. 1992 Elevated K/T palaeotemperatures throughout Northwest England: three kilometres of Tertiary erosion? Earth and Planetary Science Letters, 112, 131-145.

Lundin, E.R. \& Doré, A.G. 2002. Mid-Cenozoic post-breakup deformation in the 'passive' margins bordering the Norwegian-Greenland Sea. Marine and Petroleum Geology, 19, 79-93.

Mackay, L.M., Turner, J., Jones, S.M. \& White, N.J. 2005. Cenozoic vertical motions in the Moray Firth Basin associated with initiation of the Iceland Plume. Tectonics, 24, doi:10.1029/2004TC001683.

Mussett, A.E., Dagley, P. \& Skelhorn, R.R. 1988. Time and duration of activity in the British Tertiary Igneous Province. In: Morton, A.C. \& Parson, L.M. (eds) Early Tertiary Volcanism and the Opening of the NE Atlantic. Geological Society, London, Special Publications, 39, 337-348.

Nielsen, S.B. \& Hansen, D.L. 2000. Physical explanation of the formation and evolution of inversion zones and marginal troughs. Geology, 28. 875-878.

O'Sullivan, K.N. 1979. The sedimentology, geochemistry, and conditions of deposition of the Tertiary rocks of the Llanbedr (Mochras Farm) borehole. Report of the Institute of Geological Sciences, No. 78/24, 1-13.

Parnell, J., Green, P.F., Watt, G. \& Middleton, D. 2005. Thermal history and oil charge on the UK Atlantic margin. Petroleum Geoscience, 11, 99-112.

Praeg, D., Stoker, M.S., Shannon, P.M., Ceramicola, S., Hjelstun, B., Laberg, J.S. \& Mathiesen, A. 2005. Episodic Cenozoic tectonism and the development of the NW European 'passive' continental margin. Marine and Petroleum Geology, 22, 1007-1030.

Redfield, T.R., Osmundsen, P.T. \& Hendricks, B.W.H. 2005. The role of fault reactivation and growth in the uplift of western Fennoscandia. Journal of the Geological Society, London, 162, 1013-1030. 
Reynolds, S.D., Coblentz, D.D. \& Hillis, R.R. 2002. Tectonic forces controlling the regional intraplate stress field in continental Australia: Results from new finite element modelling. Journal of Geophysical Research, 107B, doi:10.1029/2001JB000408.

Rider, M.H. 1996. The Geological Interpretation of Well Logs (2 ${ }^{\text {nd }}$ Edition). Whittles Publishing, Caithness.

Roberts, D.G. 1989. Basin inversion in and around the British Isles. In: Cooper, M.A. \& Williams, G.D. (eds) Inversion Tectonics. Geological Society, London, Special Publications, 44, 131-150.

Rohrman, M. \& van der Beek, P. 1996. Cenozoic postrift domal uplift of North Atlantic margins: An asthenospheric diapirism model. Geology, 24, 901-904.

Rowley, E. \& White, N. 1998. Inverse modelling of extension and denudation in the East Irish Sea and surrounding areas. Earth and Planetary Science Letters, 161, 57-71.

Sclater, J.G. \& Christie, P.A.F. 1980. Continental stretching: an explanation of the post-midCretaceous subsidence of the Central North Sea Basin. Journal of Geophysical Research, 85, 3711-3739.

Scotchman, I.C. 2001. Petroleum geochemistry of the Lower and Middle Jurassic in Atlantic margin basins of Ireland and the UK. In: Shannon, P.M., Haughton, P.D.W. \& Corcoran, D.V. (eds) The Petroleum Exploration of Ireland's Offshore Basins. Geological Society, London, Special Publications, 188, 31-60.

Sibson, R.H. 1995. Selective fault reactivation during basin inversion: potential for fluid redistribution through fault-valve action. In: Buchanan, J.G. \& Buchanan, P.G. (eds) Basin Inversion. Geological Society, London, Special Publications, 88, 3-21.

Stoker, M.S., Hoult, R.J., Nielsen, T., Hjelstun, B.O., Laberg, J.S., Shannon, P.M., Praeg, D., Mathiesen, A., van Weering, T.C.E. \& McDonnell, A. 2005. Sedimentary and oceanographic responses to early Neogene compression on the NW European margin. Marine and Petroleum Geology, 22, 1031-1044.

Stuevold, L.M. \& Eldholm, O. 1996. Cenozoic uplift of Fennoscandia inferred from a study of the mid-Norwegian margin. Global and Planetary Change, 12, 359-386. 
Tappin, D.R., Chadwick, R.A., Jackson, A.A., Wingfield, R.T.R. \& Smith, N.J.P. 1994. The geology of the Cardigan Bay and the Bristol Channel. London: HMSO for the British Geological Survey.

Tiley, R., White, N. \& Al-Kindi, S. 2004. Linking Palaeogene denudation and magmatic underplating beneath the British Isles. Geological Magazine, 141, 345-351.

Thomson, K., Green, P.F., Whitham, A.G., Price, S.P. \& Underhill, J.R. 1999a. New constraints on the thermal history of North-East Greenland from apatite fission-track analysis. Geological Society of America Bulletin, 111, 1054-1068.

Turner, J.P. 1996. Gravity-driven nappes and their relation to palaeobathymetry: examples from West Africa and Cardigan Bay, UK. In: Buchanan, P.G. \& Nieuwland, D.A. (eds) Modern Developments in Structural Interpretation, Validation and Modelling. Geological Society, London, Special Publications, 99, 345-362.

Turner, J.P. 1997. Strike-slip fault reactivation in the Cardigan Bay basin. Journal of the Geological Society, London, 154, 5-8.

Turner, J.P. \& Williams, G.A. 2004. Sedimentary basin inversion and intra-plate shortening. Earth-Science Reviews, 65, 277-304.

Ware, P.D. \& Turner, J.P. 2002. Sonic velocity analysis of the Tertiary denudation of the Irish Sea basin. In: Doré, A.G., Cartwright, J., Stoker, M.S., Turner, J.P. \& White, N. (eds) Exhumation of the North Atlantic Margin: Timing, Mechanisms and Implications for Petroleum Exploration. Geological Society, London, Special Publications, 196, 355-370.

Welch, M.J. \& Turner, J.P. 2000. Triassic-Jurassic development of the St. George's Channel basin, offshore Wales, UK. Marine and Petroleum Geology, 17, 723-750.

White, N. \& Lovell, B. 1997. Measuring the pulse of a plume with the sedimentary record. Nature, 387, 888-891.

White, R.S. \& McKenzie, D.P. 1989. Magmatism at Rift Zones: The Generation of Volcanic Continental Margins and Flood Basalts. Journal of Geophysical Research, 94B, 7685-7729. 
Williams, G.A., Turner, J.P. \& Holford, S.P. 2005. Inversion and exhumation of the St George's Channel Basin, offshore Wales, UK. Journal of the Geological Society, London, 162, $97-110$.

Williams, G.D., Powell, C.M. \& Cooper, M.A. 1989. Geometry and kinematics of inversion tectonics. In: Cooper, M.A. \& Williams, G.D. (eds) Inversion Tectonics. Geological Society, London, Special Publications, 44, 3-15.

Woodland, A.W. (ed.) 1971. The Llanbedr (Mochras Farm) borehole. Report of the Institute of Geological Sciences, No. 71/18.

Yalçin, M.N., Littke, R. \& Sachsenhofer, R.F. 1997. Thermal history of sedimentary basins. In: Welte, D.H., Horsfield, B. \& Baker, D.R. (eds) Petroleum and Basin Evolution, Springer, 71-167.

Ziegler, P.A. 2004. Europe: Permian to Recent Evolution. In: Selley, R.C., Cocks, L.R., Plimer, I.R. (eds) The Encyclopedia of Geology. Elsevier, Amsterdam, 102-125.

Ziegler, P.A., Cloetingh, S. \& van Wees, J-D. 1995. Dynamics of intra-plate compressional deformation: the Alpine foreland and other examples. Tectonophysics, 252, 7-59.

Ziegler, P.A., van Wees, J-D. \& Cloetingh, S. 1998. Mechanical controls on collision-related compressional intraplate deformation. Tectonophysics, 300, 103-129. 


\section{Figure captions}

\section{Figure 1}

Pre-Pleistocene offshore geology of the southern Irish Sea basin system.

\section{Figure 2}

Log of the Cenozoic sediments in the Mochras borehole, after Tappin et al. (1994). The lithostratigraphical units were erected by O'Sullivan (1979) on the basis of sonic, density and gamma ray logs, where breaks occur at depths of 280 and $405 \mathrm{~m}$.

\section{Figure 3}

Approximately East-West trending cross section through the Cardigan Bay Basin based on the interpretation of a BGS seismic reflection profile, extended to the Mochras Fault. Modified after Tappin et al. (1994).

\section{Figure 4}

Process involved with extracting a thermal history solution from AFTA data for Mochras sample GC399-13. Four separate thermal history scenarios are shown (a), and for each, the predicted track length distribution is compared with the observed track length distribution. Corresponding predicted trends of fission track age vs. wt $\% \mathrm{Cl}$ are compared with measured data in (b). Four modelled scenarios are shown; (i) Maximum palaeotemperature attained prior to early Cretaceous cooling, with additional cooling from a subsequent but lower palaeotemperature peak during the Neogene (best-fit scenario). (ii) Default thermal history, which is constructed using the preserved stratigraphy recorded in the borehole, assuming that all stratigraphic breaks represent hiatuses (i.e. no deposition or erosion). A thermal history is then derived by assuming that the present geothermal gradient has remained constant through time since the deposition of the oldest sediments. (iii) Maximum palaeotemperatures reached prior to Neogene cooling, with no early Cretaceous episode. (iv) Maximum palaeotemperatures reached prior to early Cretaceous cooling, with no Neogene event. The thermal history solution involving an early Cretaceous maximum and a lower Neogene peak clearly provides the best fit to the measured track length distribution and the variation of fission track age vs. wt\% Cl. Scenarios involving only one phase of cooling and which omit either the early or late cooling events cannot adequately explain all facets of the fission-track length and age data.

\section{Figure 5}

Schematic illustration of the preferred thermal history interpretation for AFTA sample GC399-13. Rectangular boxes represent estimates of timing and temperatures of palaeothermal episodes within $\pm 95 \%$ confidence limits. Estimate of timing of early Cretaceous exhumation episode based on regional AFTA dataset reported in Holford (2006). Timing of magmatic activity related to the British Cenozoic Igneous Province based on Mussett et al. (1988). Mochras stratigraphy based on Woodland (1971) and Tappin et al. (1994).

\section{Figure 6}

Palaeotemperature constraints from AFTA and VR data from the Mochras borehole plotted against depth. These are used to infer palaeotemperature profiles prior to Neogene and early Cretaceous cooling episodes, whilst corrected BHT data are used to define the present-day geothermal gradient. A simplified stratigraphic column is also shown. Full details of AFTA and VR data from the Mochras borehole are presented in Holford et al. (2005a)

\section{Figure 7}

Amounts of additional section and palaeogeothermal gradients required to explain the (a) early Cretaceous and (b) Neogene palaeothermal episodes recorded by AFTA and VR data from Mochras. Shaded region defines the allowed range of values for each parameter that are consistent with the 
measured palaeotemperature constraints within $95 \%$ confidence limits. Black dots represent the maximum likelihood estimates. The magnitude of removed section for each episode consistent with a palaeogeothermal gradient with a similar value to the present-day gradient $\left(23.4^{\circ} \mathrm{C} \mathrm{km}^{-1}\right)$ is indicated. Shaded horizontal bars indicate the range of exhumation estimates for each episode as calculated from porosity data (see Figure 8).

\section{Figure 8}

Density and calculated porosity data for the Mochras borehole. The density log was filtered to remove spurious data and unwanted (i.e. non-shale) lithologies following the procedures reported in Holford et al. (2005a). For shales, the largest source of error when converting density data to porosities arises from the highly variable nature of shale matrix densities (Rider 1996). For this reason, two sets of porosities have been calculated using end member matrix densities of $2.67 \mathrm{~g} / \mathrm{cm}^{3}$ and $2.72 \mathrm{~g} / \mathrm{cm}^{3}$. Error bars represent \pm 1 standard deviation. (a) Bulk density $\left(\mathrm{g} / \mathrm{cm}^{3}\right)$ data for the Mochras borehole. Note the abrupt increase in density across the Cenozoic/Jurassic unconformity. (b) Porosities calculated using equation (2) assuming a matrix density of $2.67 \mathrm{~g} \mathrm{~cm}^{-3}$. Neogene (calculated using Oligo-Miocene porosity data) and early Cretaceous (calculated using Lower Jurassic porosity data) apparent and total exhumation estimates (cf. Hillis 1995) relative to the Sclater \& Christie (1980) shale porosity-depth trend. (c) Porosity data and exhumation estimates calculated assuming a matrix density of $2.72 \mathrm{~g} \mathrm{~cm}^{-3}$.

\section{Figure 9}

Two reconstructed burial histories for the Mochras borehole. Both histories incorporate $2.5 \mathrm{~km}$ of Middle and Upper Jurassic sediments removed during early Cretaceous exhumation, and $1.5 \mathrm{~km}$ of Miocene sediments removed during late Neogene exhumation. Both models assume a constant geothermal gradient through time, with a similar value to the present-day temperature profile $\left(\right.$ c. $23.4^{\circ} \mathrm{C}$ $\mathrm{km}^{-1}$ ). Vertical light grey shaded bars represent estimates of the onset of exhumation-related cooling as indicated by AFTA sample GC399-13, whilst dark grey bars represent the overall estimates of the onset of exhumation based on stratigraphic constraints and regional AFTA results. (a) The first history assumes no burial or exhumation during late Cretaceous-early Paleogene times, whilst (b) the second burial history incorporates $0.8 \mathrm{~km}$ of Upper Cretaceous section, removed during an early Paleogene exhumation event. Assuming an invariant geothermal gradient of $23.4^{\circ} \mathrm{C} \mathrm{km}^{-1}, 0.8 \mathrm{~km}$ is the maximum amount of early Paleogene exhumation that could have occurred without affecting the measured AFTA parameters (cf. Fig. 5).

\section{Figure 10}

(a-d) Structural contours at basal Triassic (a), top Triassic (b), basal Cenozoic (c) and intra-Eocene levels (d) based on seismic mapping in the SGCB. Contours are in two-way travel time and fault traces are shaded black. Note the presence of a broad NW-SE trending anticline which is confined to the Cenozoic succession (c-d) and the core of which is penetrated by exploration wells $106 / 24 a-2 b$ and 106/24-1. Note also the coincidence of structural culminations with right-stepping bends on the main NE-trending fault systems. This is interpreted as a consequence of their reactivation in left-lateral shear during Neogene transpressional shortening of the basin. After Williams et al. (2005).

\section{Figure 11}

Seismic profile and accompanying interpretation through a severely reactivated segment of the Bala Fault, along the SE margin of the St George's Channel Basin. Neogene shortening has been accommodated by reverse displacement along the low-angle Bala Fault. The Bala Fault has a ramp-flat geometry, and the buttressing effect of the ramp arrested reverse displacement with further shortening accommodated by the formation of a NW-trending thrust fault splaying from the Bala Fault. Note the significant structural dip of the Cenozoic (Eocene-Oligocene) sequence, which is almost parallel with that of the Mesozoic succession. Modified after Williams et al. (2005). 


\section{Figure 12}

(a) Palaeotemperature-depth plot for SGCB exploration well 106/24a-2b. (b) Amounts of additional section and palaeogeothermal gradients required to explain the palaeotemperatures prior to Neogene exhumation at this location. The shaded region defines the allowed range of values for each parameter that are consistent with the measured palaeotemperature constraints within $95 \%$ confidence limits. Black dots represent the maximum likelihood estimates. (c) Burial history plot for well 106/24a-2b, reconstructed using (i) the preserved stratigraphy penetrated by the well and (ii) constraints on deeper burial and thermal history provided by palaeothermal and compaction data. This shows that maximum burial depths at 106/24a-2b were reached prior to Neogene exhumation. This scenario incorporates $c$. 1 $\mathrm{km}$ of exhumation during the early Paleogene, although it is emphasised that palaeothermal data place no constraints on the amount of exhumation at this time.

\section{Figure 13}

(a) Palaeotemperature-depth plot for SGCB exploration well 106/24-1. (b) Amounts of additional section and palaeogeothermal gradients required to explain the palaeotemperatures prior to Neogene exhumation at this location. The shaded region defines the allowed range of values for each parameter that are consistent with the measured palaeotemperature constraints within $95 \%$ confidence limits. Black dots represent the maximum likelihood estimates. (c) Burial history plot for well 106/24-1, showing that maximum burial depths were reached prior to Neogene exhumation. As with 106/24a-2b, this scenario also incorporates $c .1 \mathrm{~km}$ of exhumation during the early Paleogene.

\section{Figure 14}

(a) Palaeotemperature-depth plot for SGCB exploration well 106/28-1. (b) Amounts of additional section and palaeogeothermal gradients required to explain the palaeotemperatures prior to Neogene exhumation at this location. The shaded region defines the allowed range of values for each parameter that are consistent with the measured palaeotemperature constraints within $95 \%$ confidence limits. Black dots represent the maximum likelihood estimates. (c) Burial history plot for well 106/28-1, showing that maximum burial depths were reached prior to Neogene exhumation. As with previous examples, this scenario also incorporates $c .1 \mathrm{~km}$ of exhumation during the early Paleogene.

\section{Figure 15}

Comparison between estimates of the magnitude of Neogene exhumation at various well locations in the St. George's Channel and Cardigan Bay basins obtained from three different methods: thermal history analysis (AFTA and VR data), sonic velocity analysis and reconstructions of the thickness of eroded section from interpretations of reflection seismic data. The quoted values from thermal history data estimates assuming that palaeogeothermal gradients were equivalent to the values of the presentday gradient. The estimates for each well are generally in good agreement, indicating a maximum of $1.5 \mathrm{~km}$ of Neogene erosion across the southern Irish Sea.

\section{Figure 16}

Seismic line through well 107/16-1 located in the NE SGCB. The section is displayed with a significant component of vertical exaggeration to highlight the reactivated fault plane that cuts well 107/16-1.

\section{Figure 17}

Cross section through the southern Irish Sea, from the St George's Channel Basin to the Central Irish Sea Basin, through the St Tudwal's Arch (offshore Llŷn Peninsula). This cross section exemplifies the inversion of structural relief which often occurs during the compressional shortening of sedimentary basins; note how the syntectonic Lower-Middle Jurassic depocentre exhibits pronounced thickening towards the uplifted structural culmination of St Tudwal's Arch. Note also, to the immediate SE of St Tudwal's Arch, and anticline within the Jurassic succession, the crest of which has been truncated by the base Palaeogene succession, indicating a pre-Neogene (early Palaeogene?) phase of compressional deformation within the southern Irish Sea. 


\section{Figure 18}

Cenozoic event stratigraphy diagram for the British Isles and Atlantic margin. Constraints on the onset of exhumation-related cooling provided by AFTA data from both within and outwith the Irish Sea basin system are compared with stratigraphic constraints on the timing of exhumation in an attempt to identify the timing of regional Neogene exhumation. This analysis suggests a regional onset of exhumation beginning between 20 and $15 \mathrm{Ma}$. The timing of important regional tectonic events, derived from Lundin \& Doré (2002) and Stoker et al. (2005) are highlighted for comparative purposes. Timescale modified after Gradstein et al. (2004). 


\section{Figure 1}

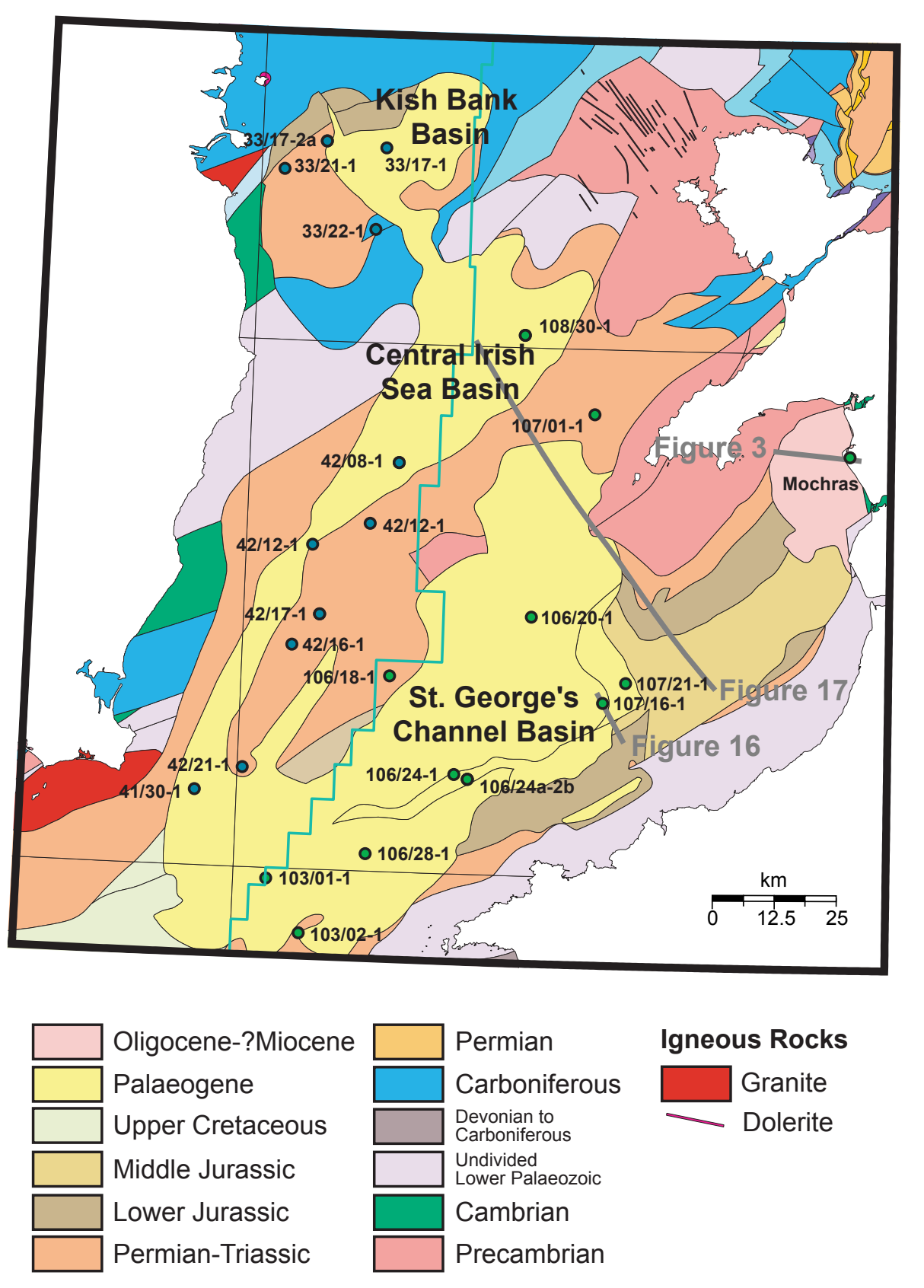


Figure 2

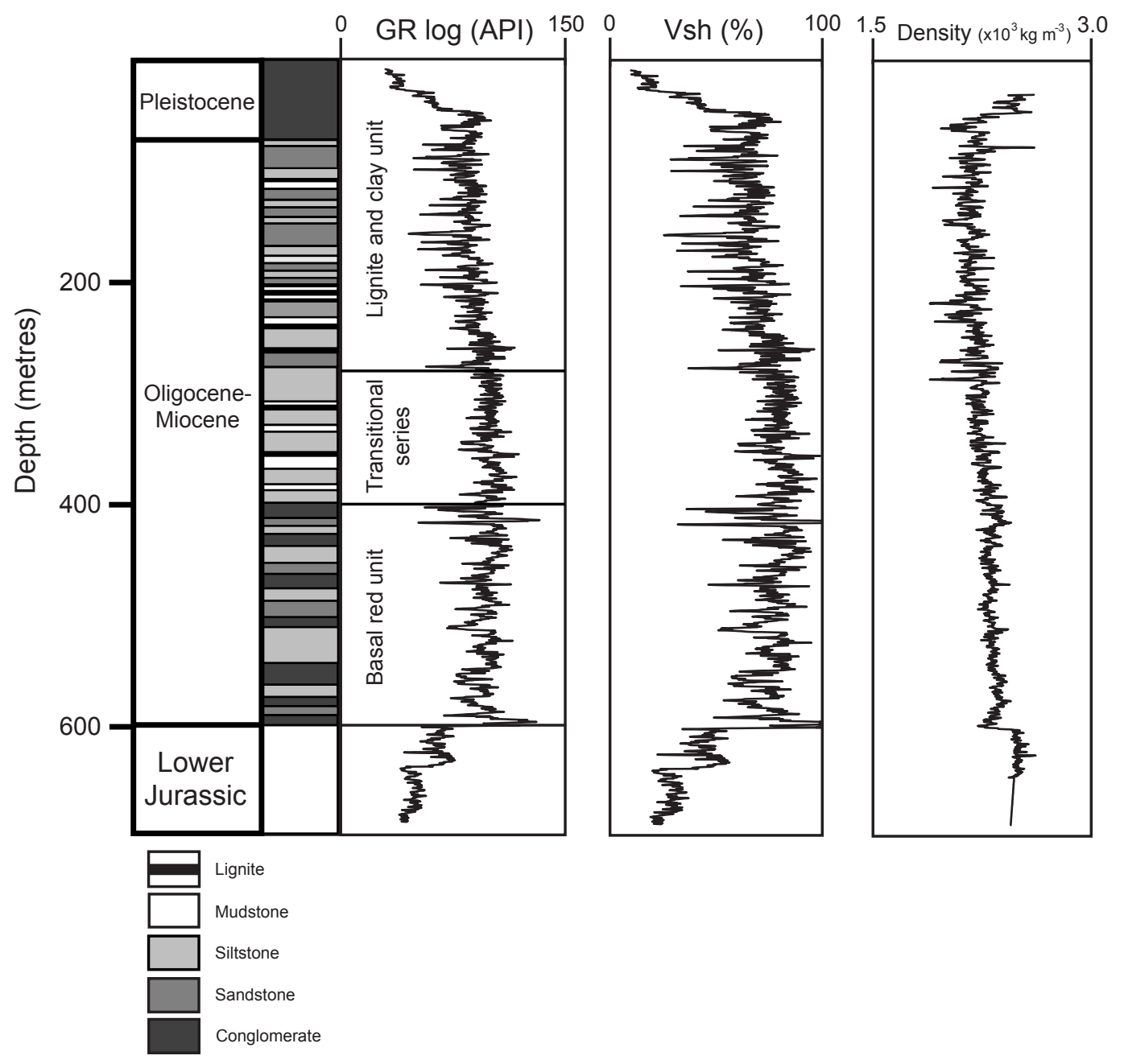


Figure 3

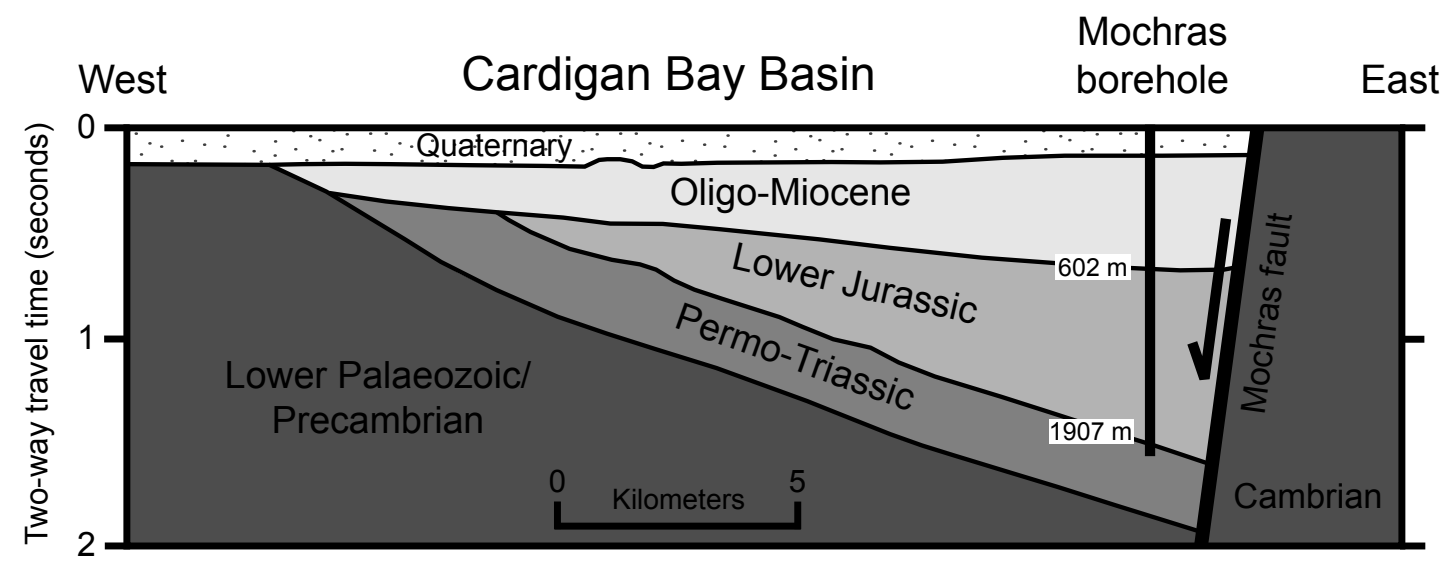


Figure 4

(a)

(i)
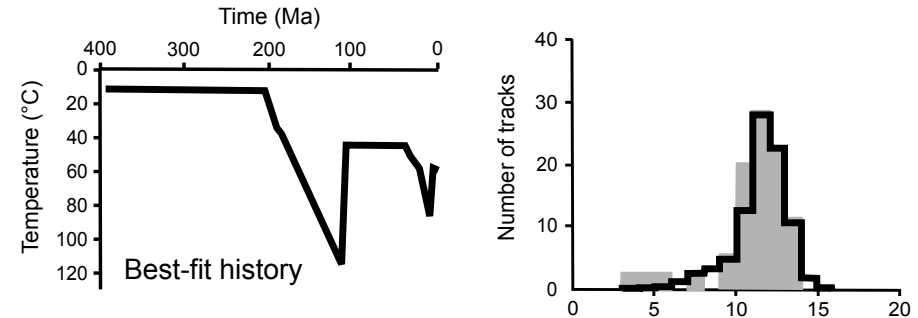

(iii)
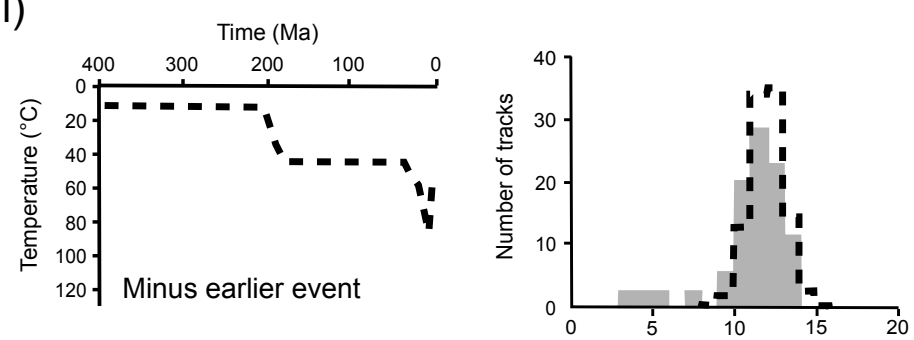

(iv)
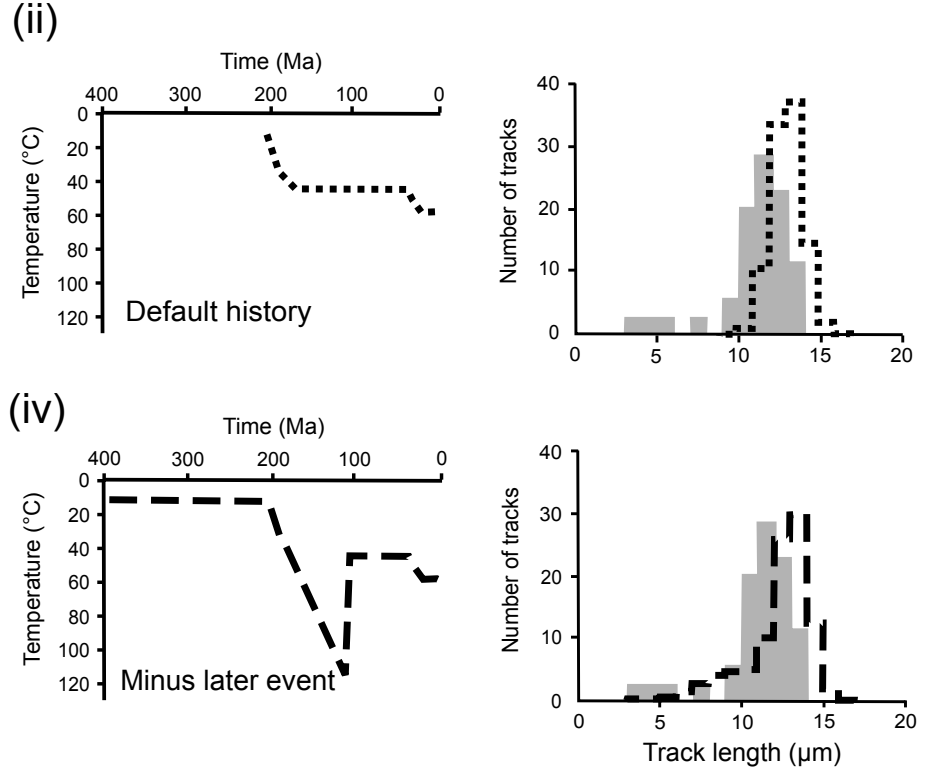

Track length $(\mu \mathrm{m})$

(b)

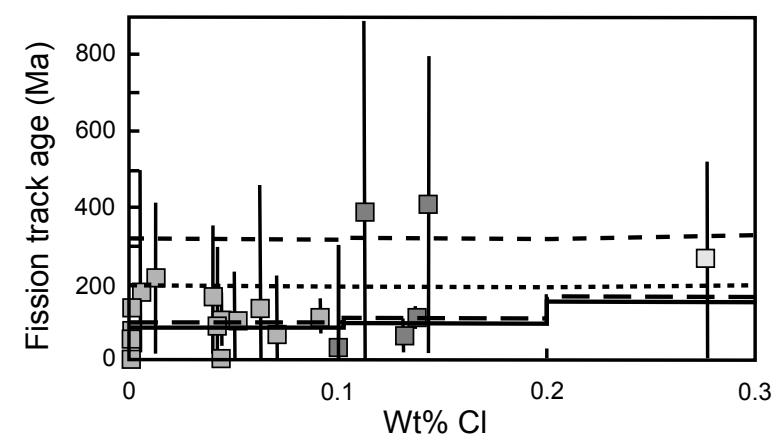


Figure 5
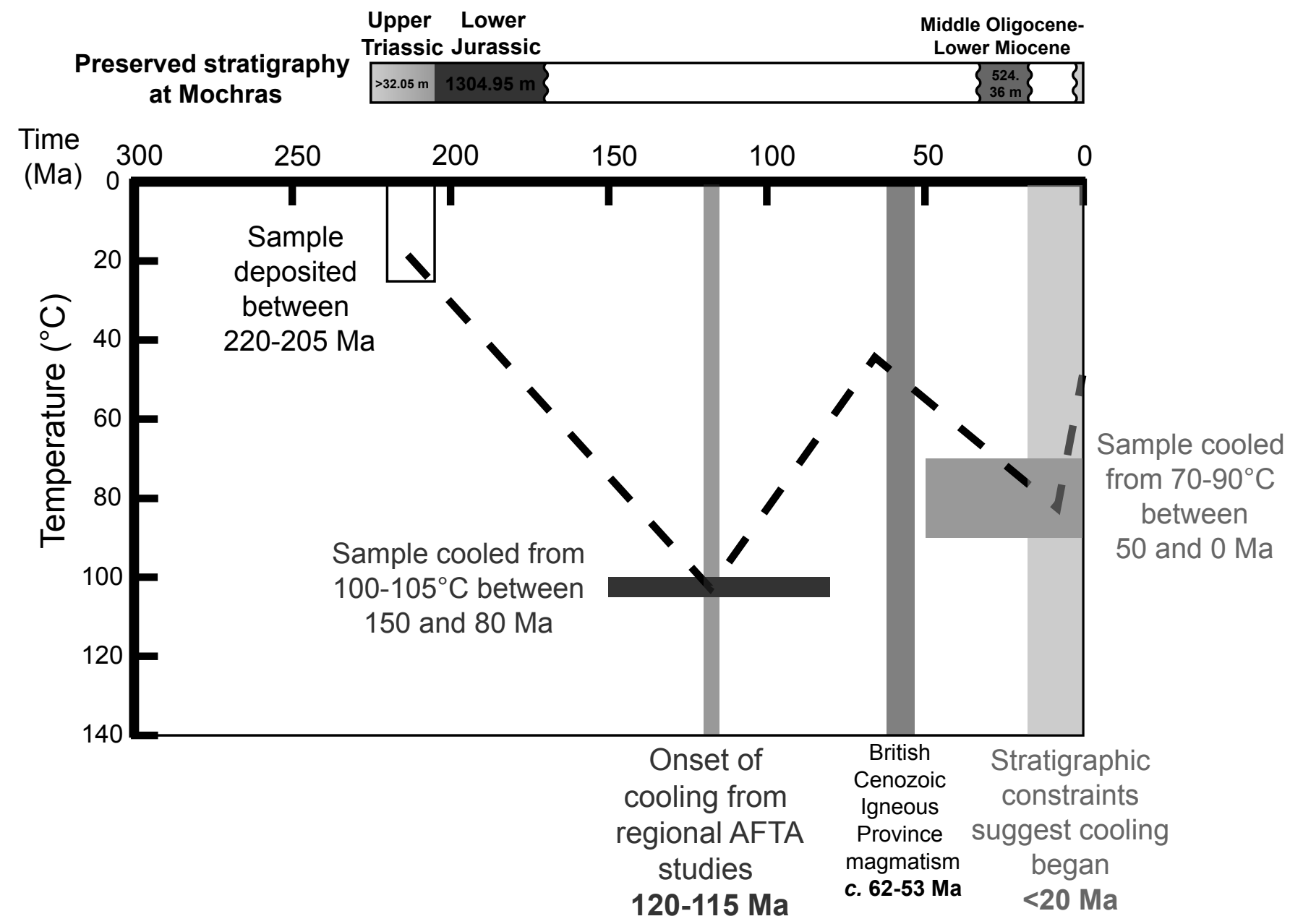
Figure 6

\section{Mochras borehole}

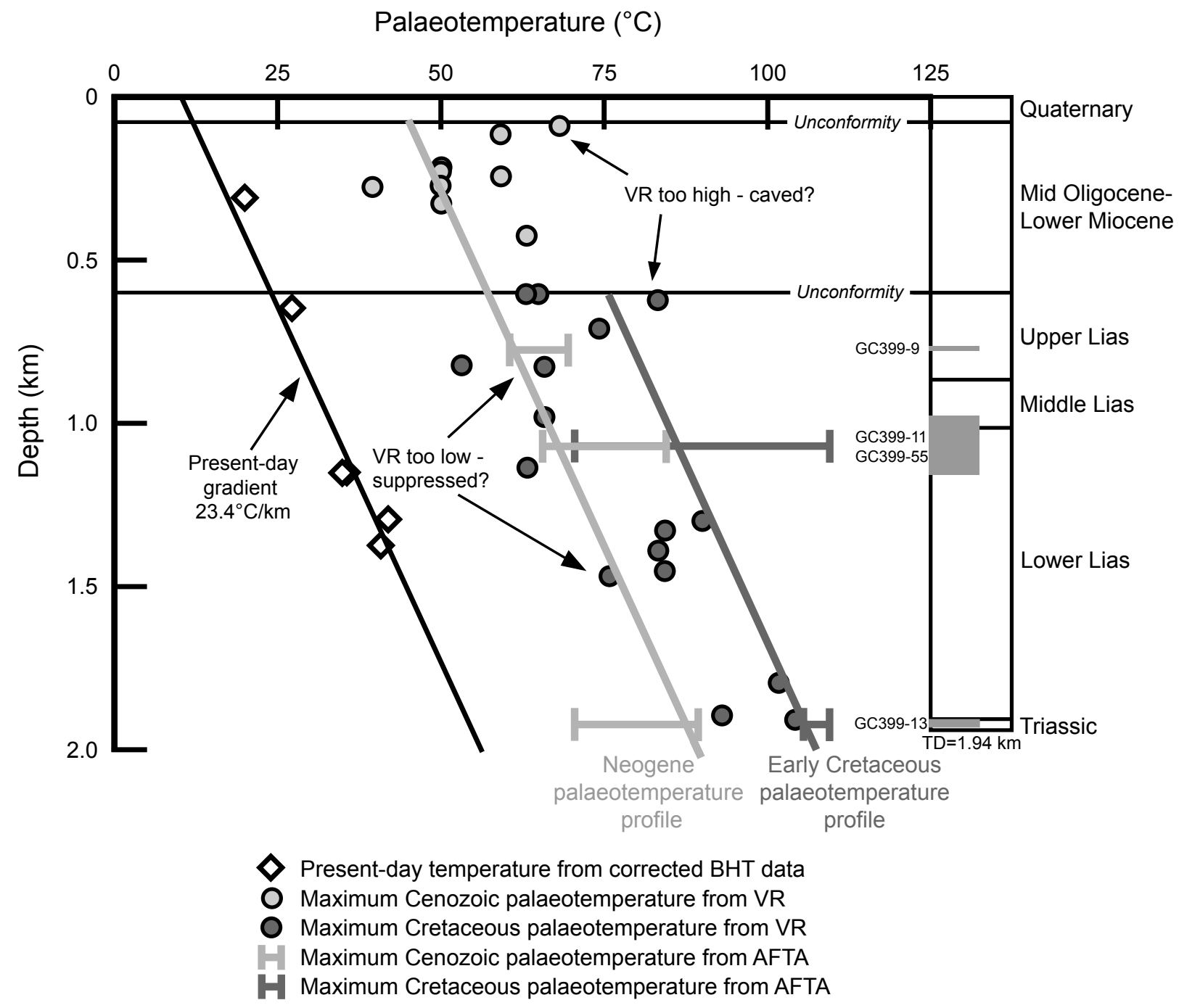


Figure 7

(a)

\section{Mochras borehole}

Early Cretaceous

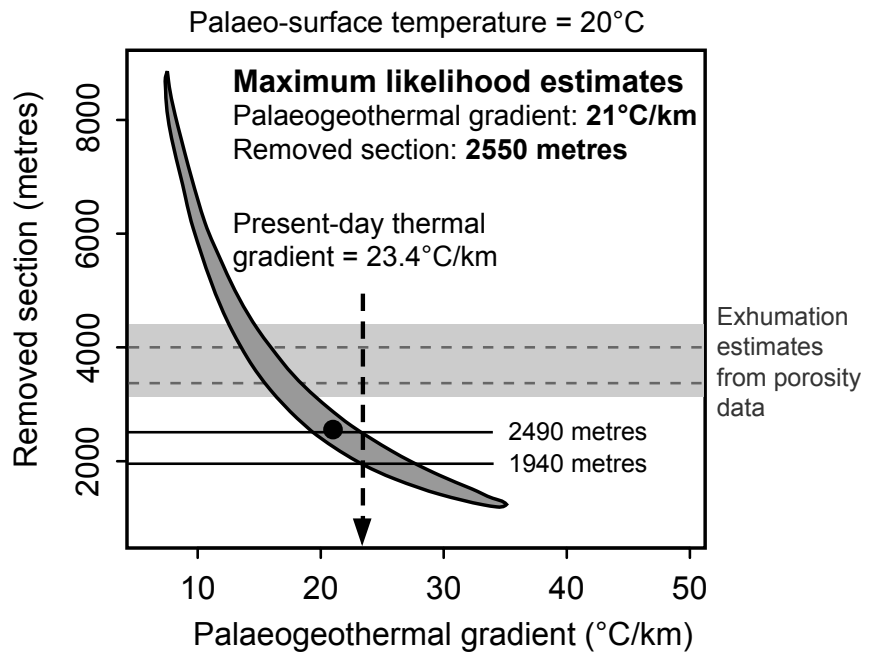

(b) Mochras borehole

Neogene

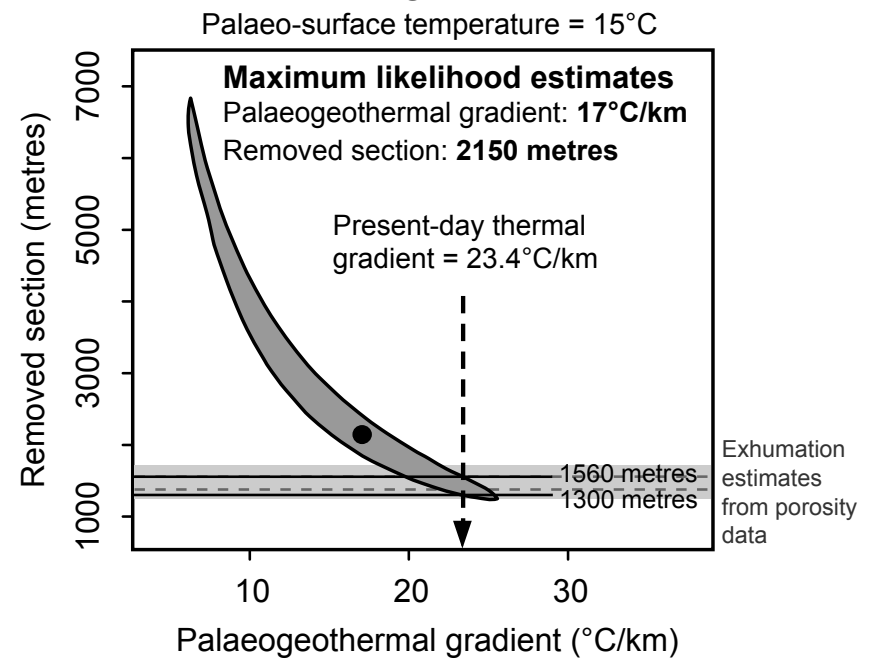


Figure 8

\section{Mochras borehole}

(a)

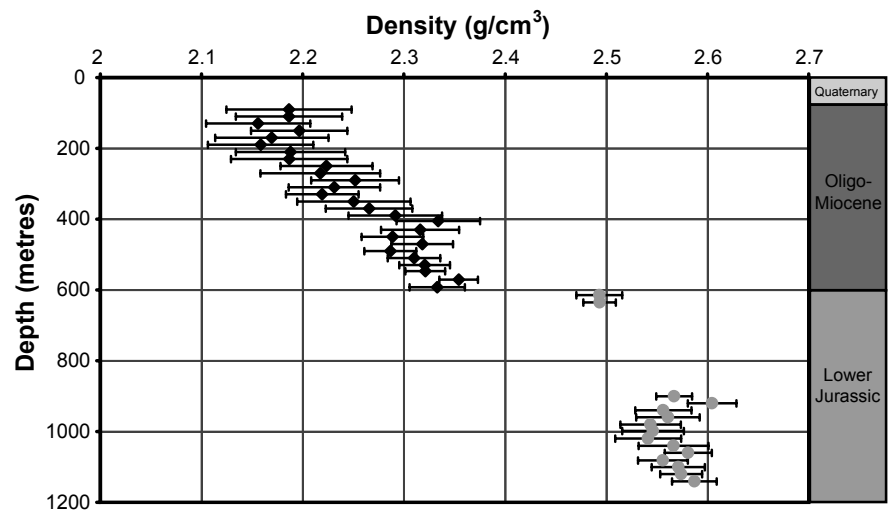

(b)

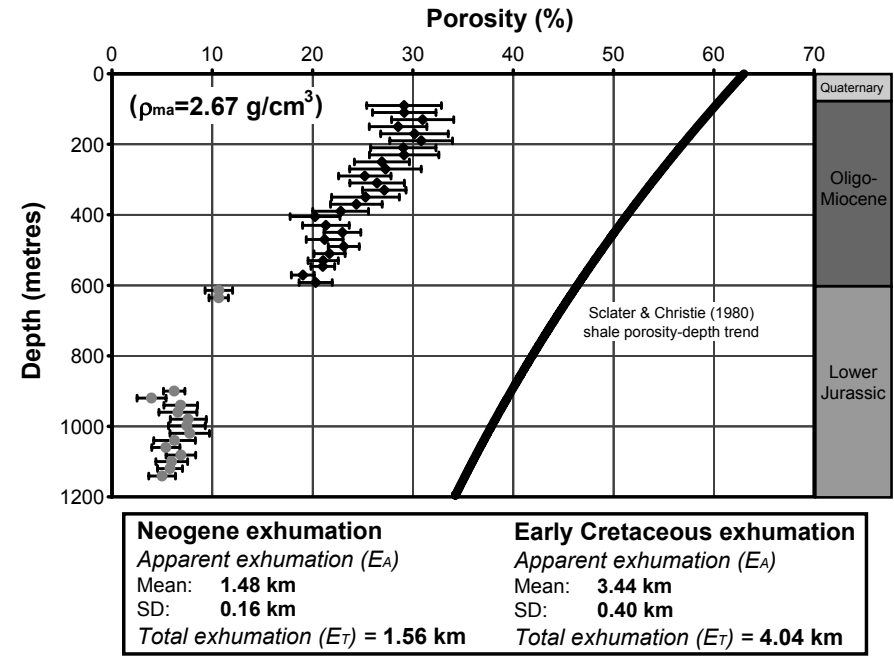

(c)

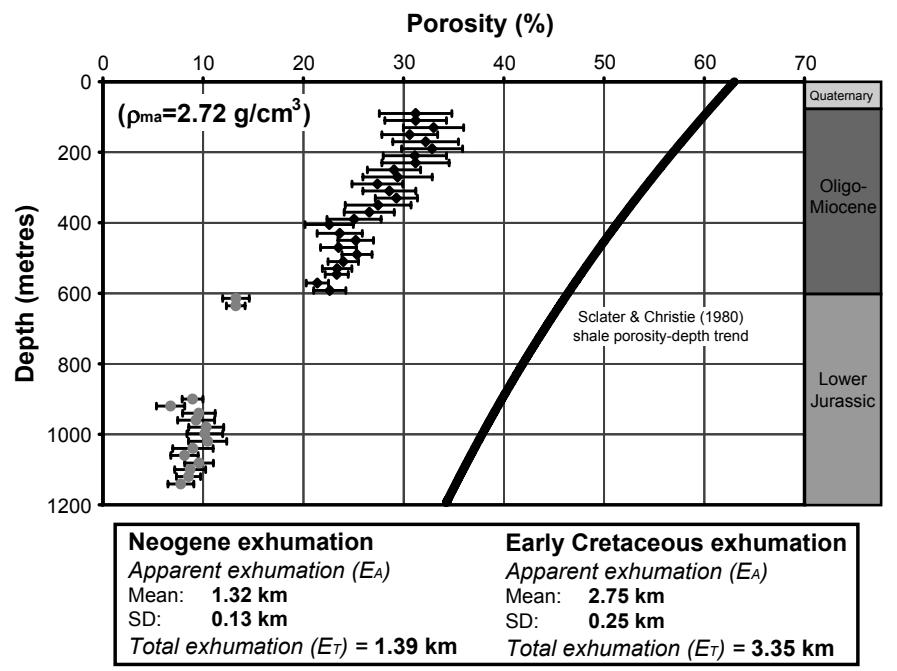


Figure 9

\section{Mochras borehole}

(a) Model 1 - no early Palaeogene exhumation

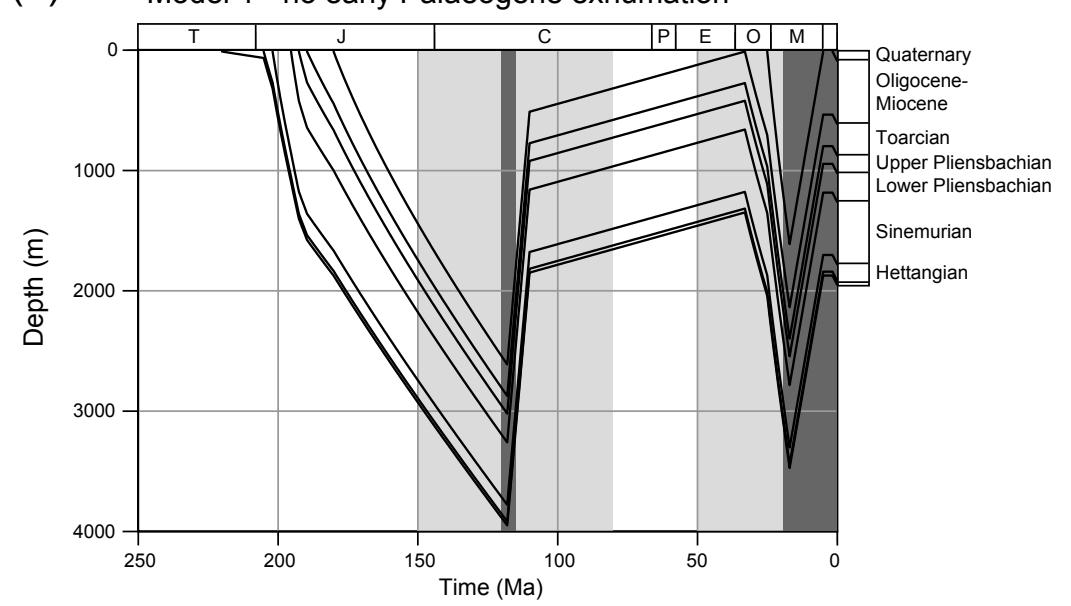

(b) Model $2-0.8 \mathrm{~km}$ of early Palaeogene exhumation

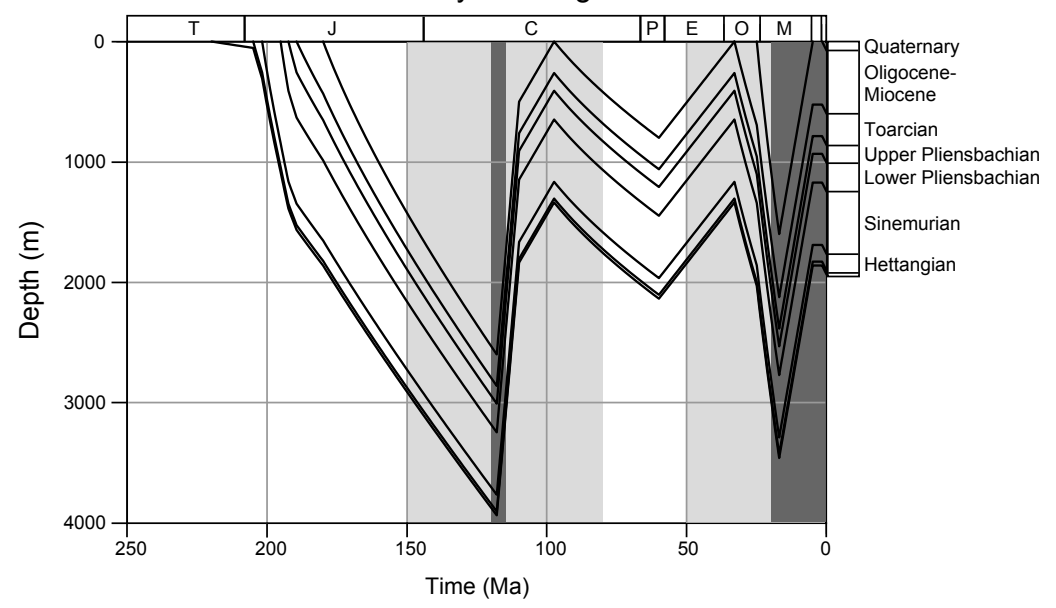


Figure 10

(a)

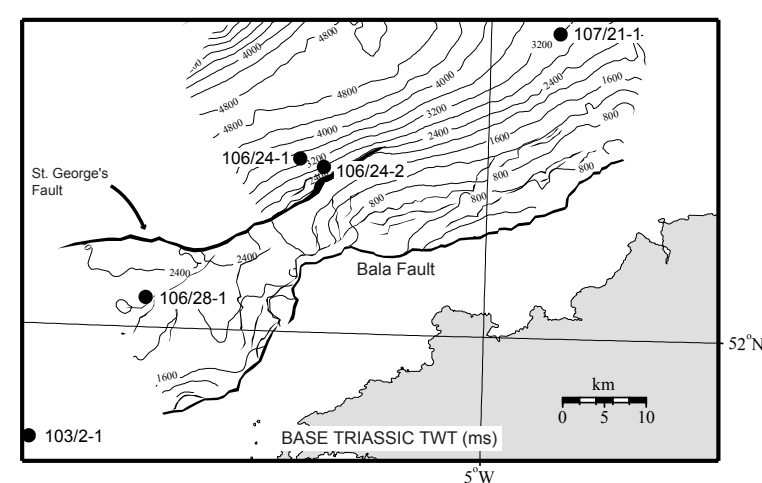

(c)

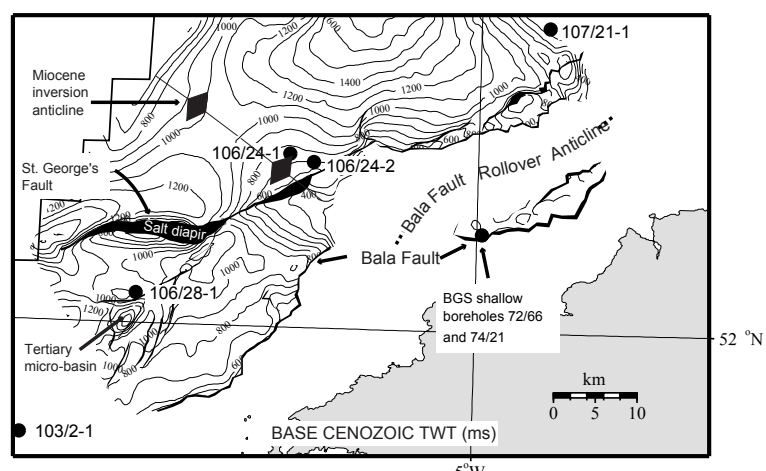

(b)

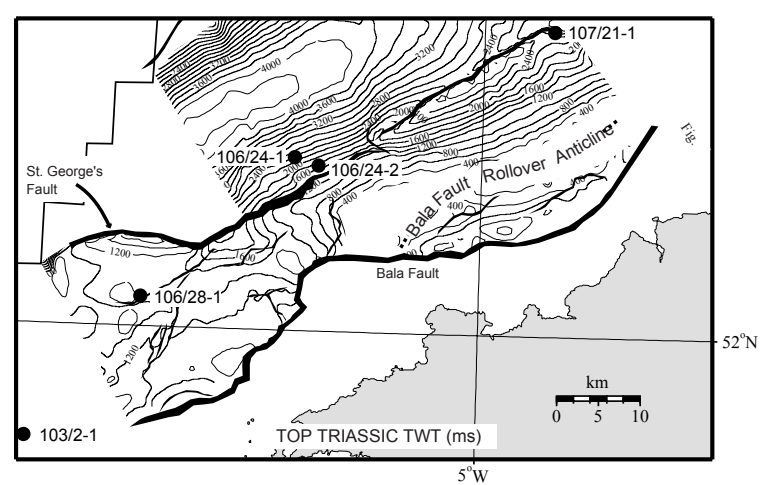

d)

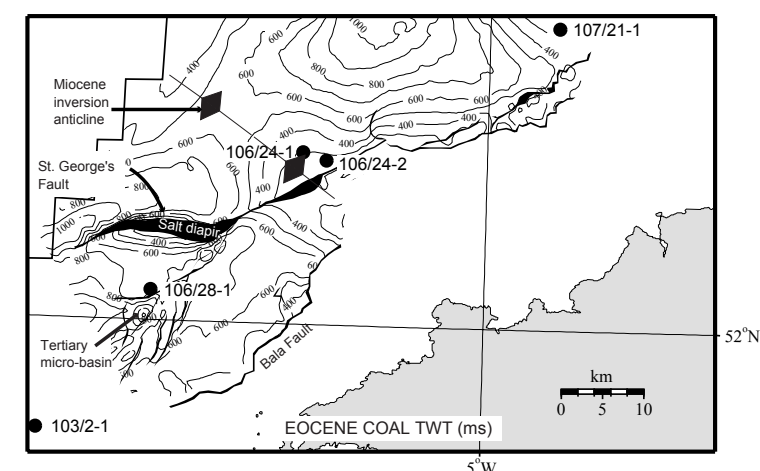




\section{Figure 11}
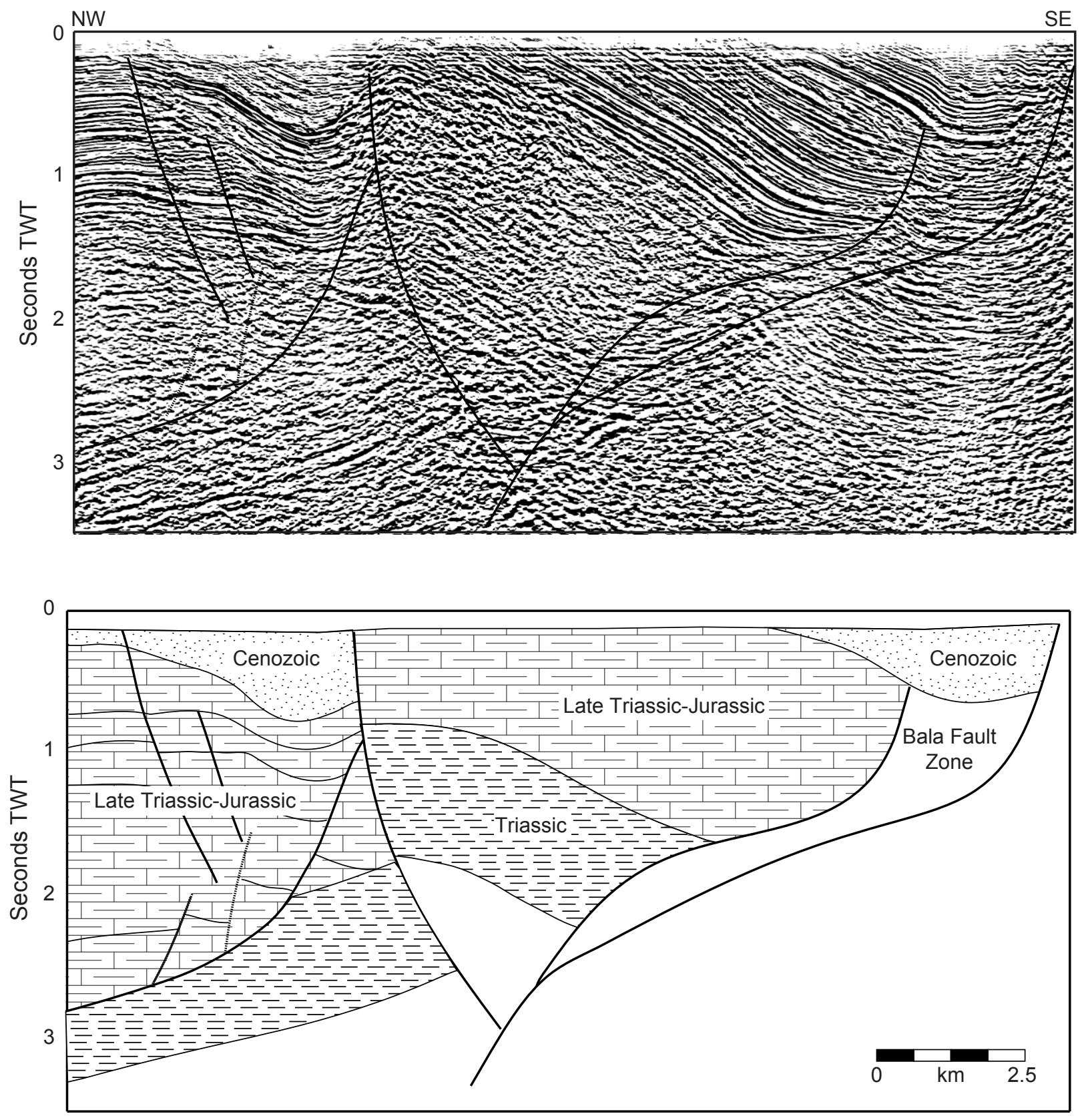
Figure 12

(a)

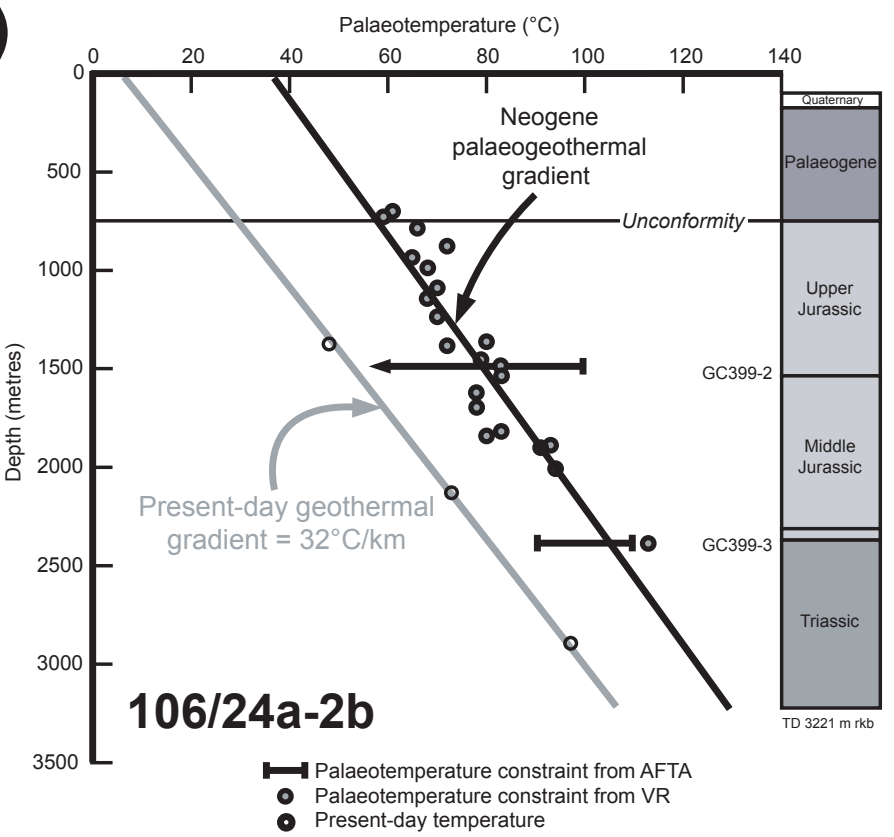

(b)

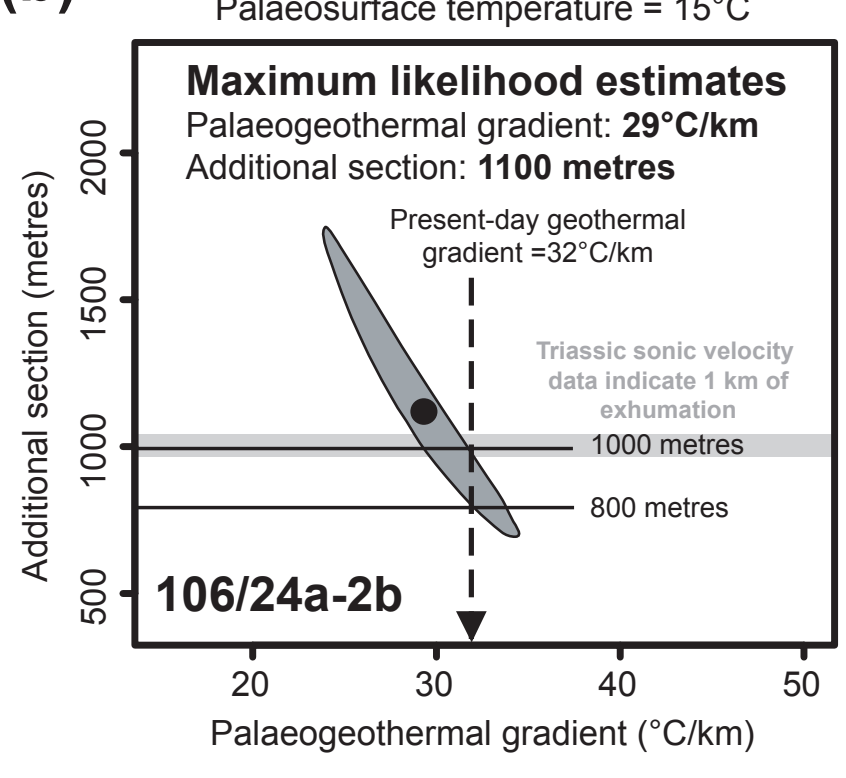

(c)

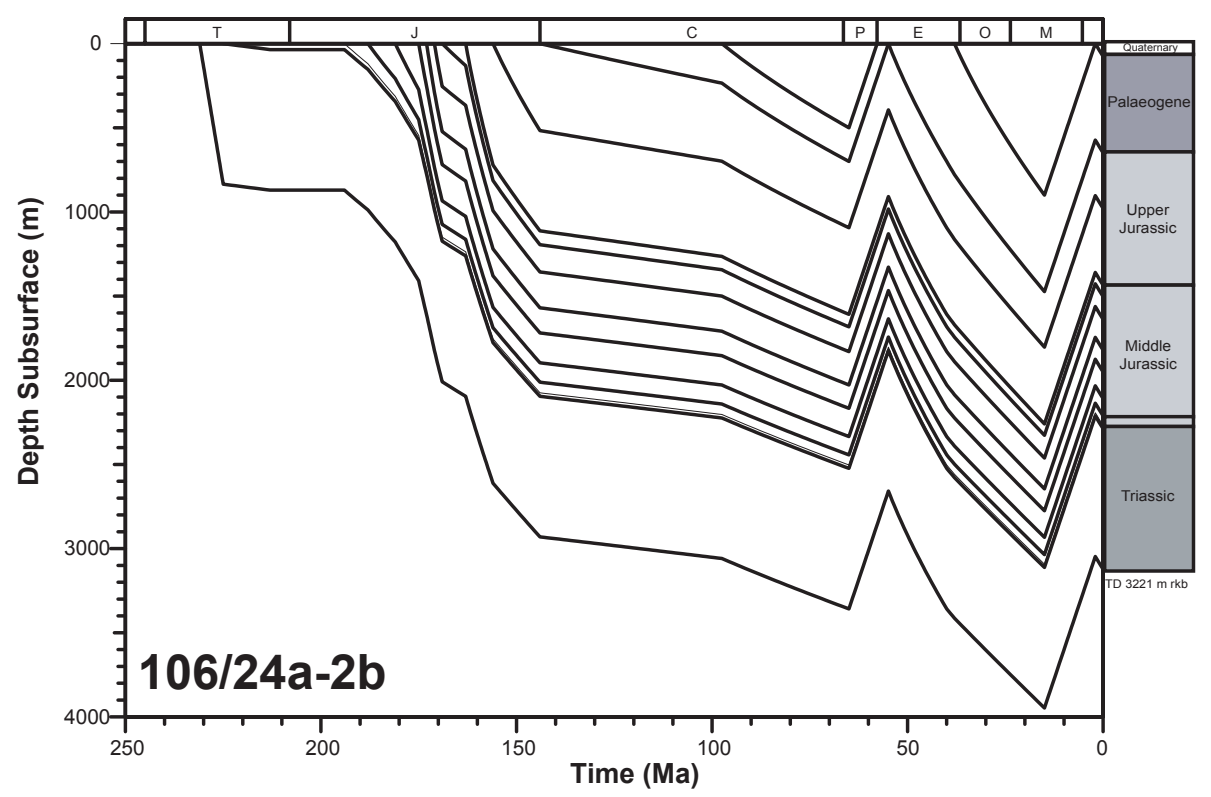


Figure 13

(a)

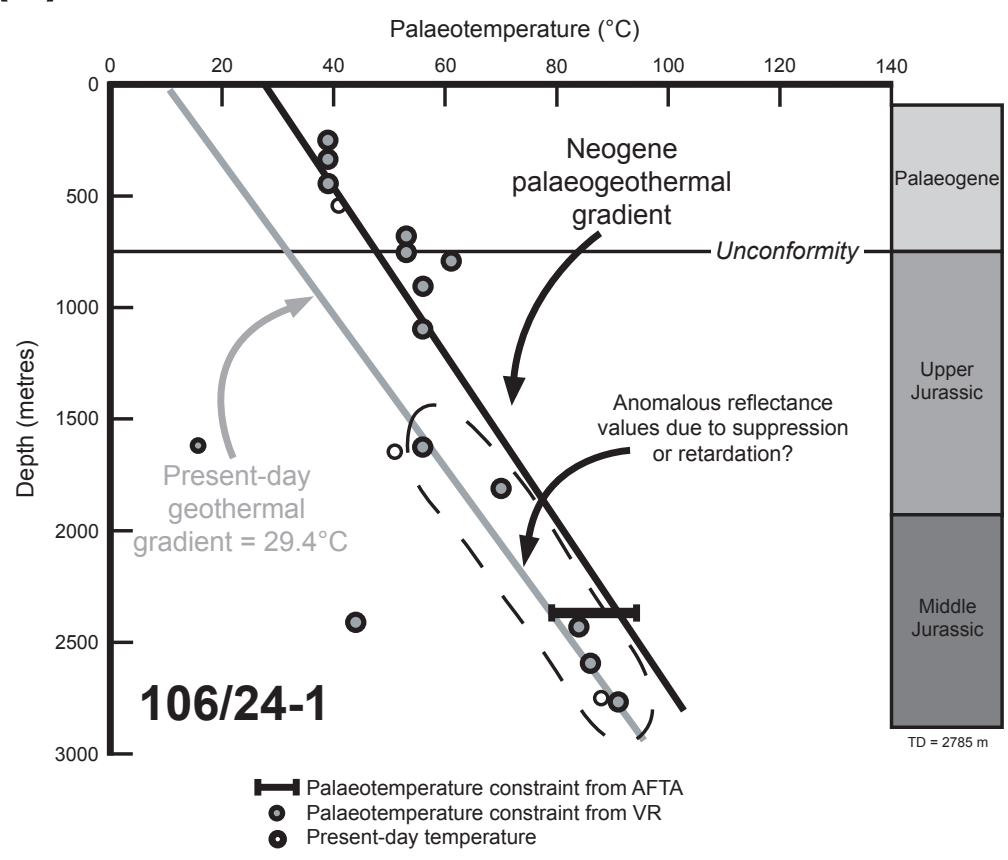

(b)

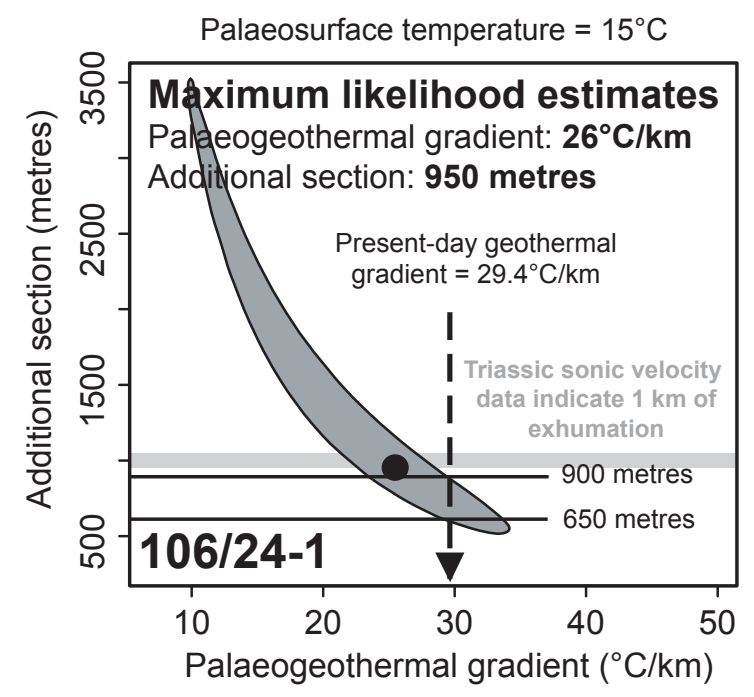

(c)

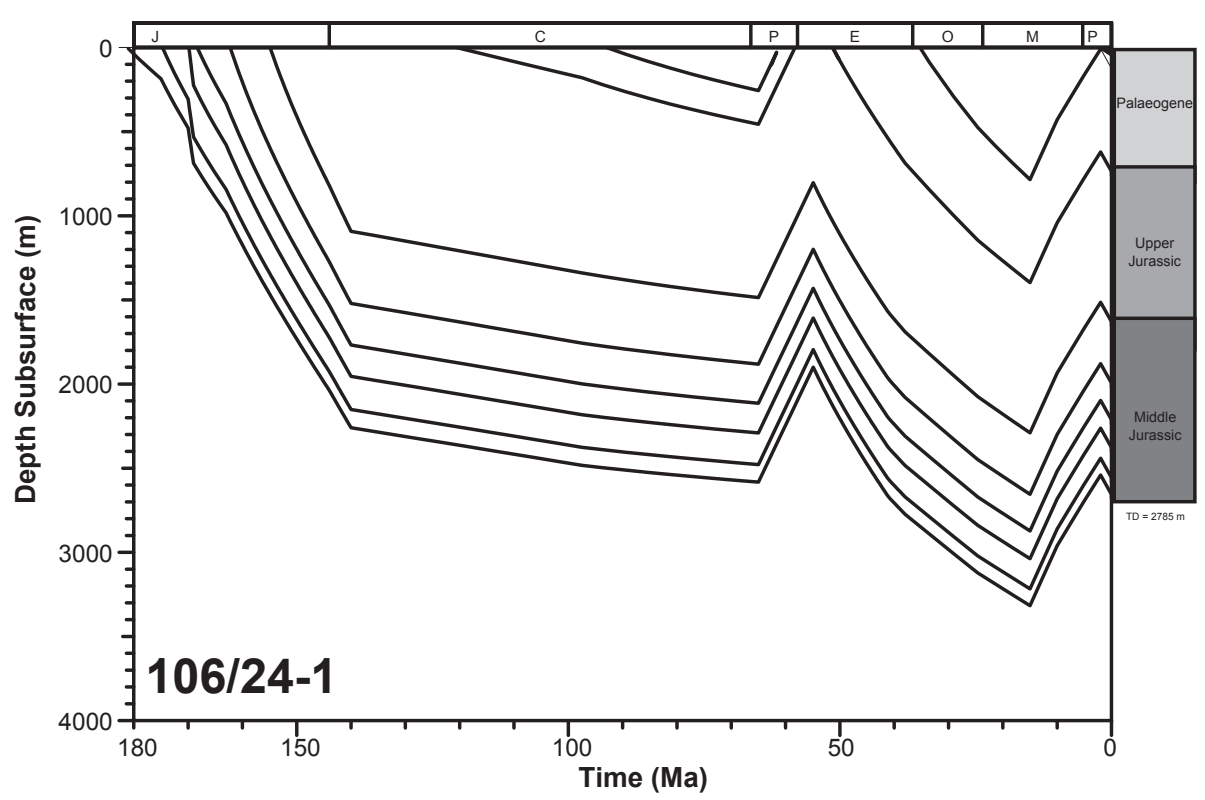




\section{Figure 14}

(a)

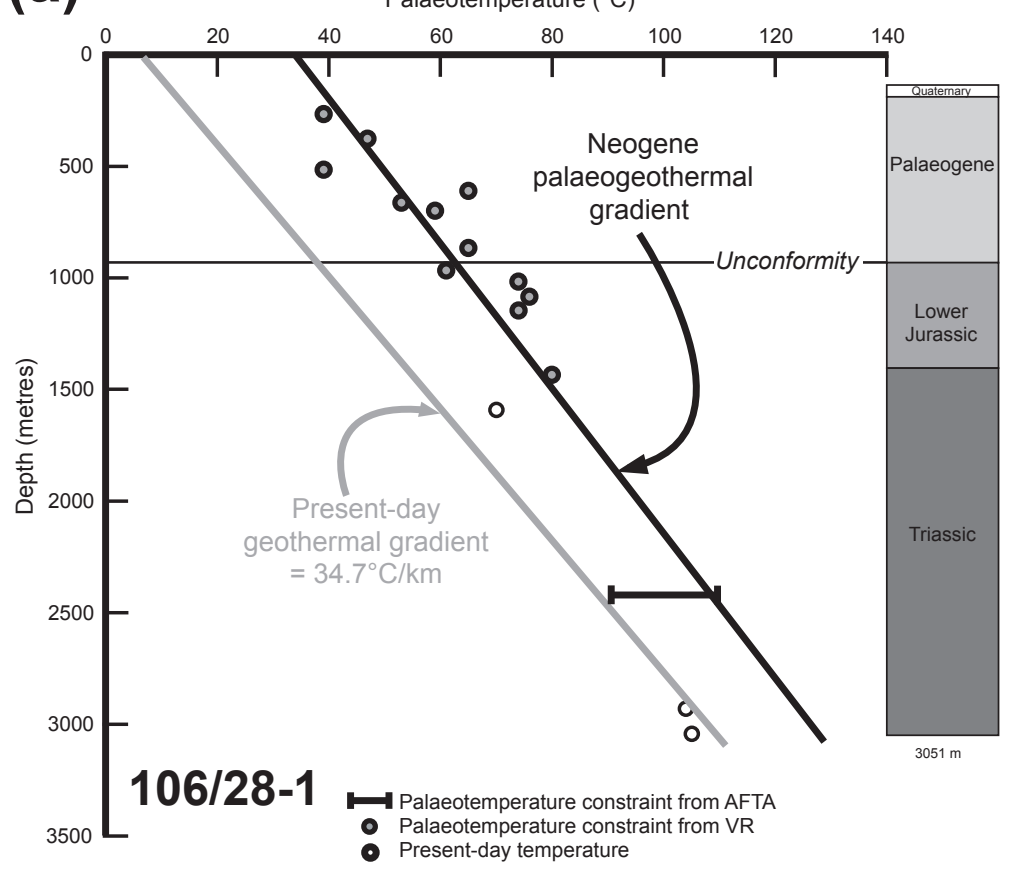

(b)

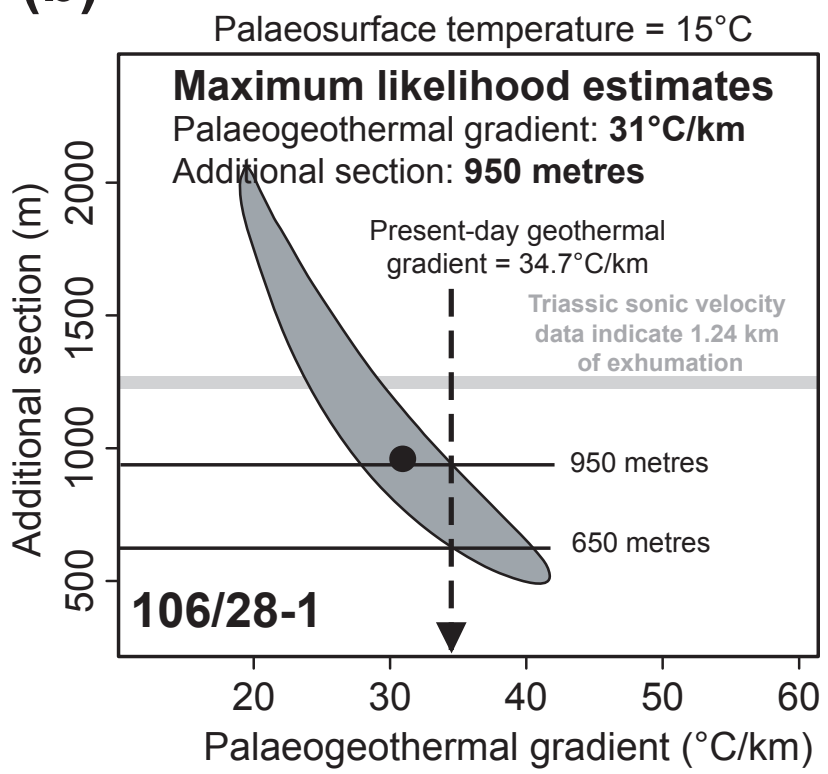

(c)

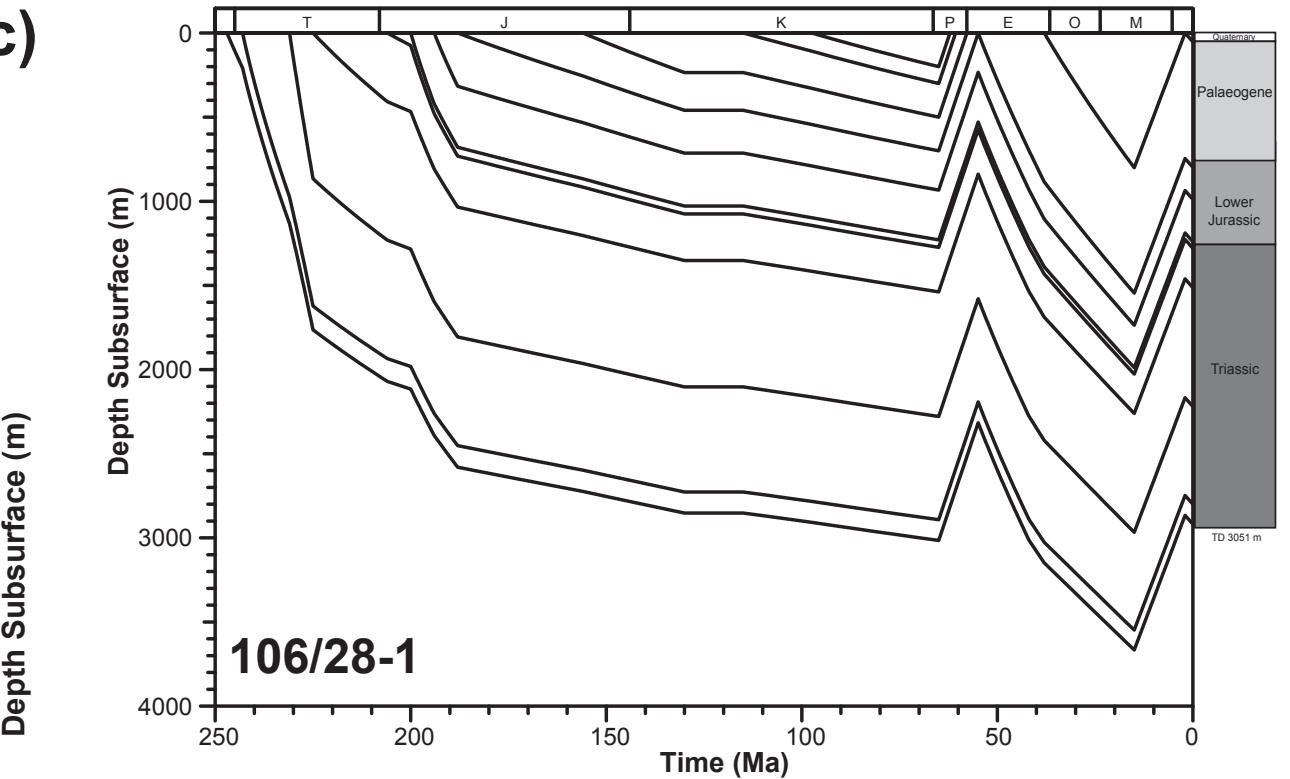


Figure 15

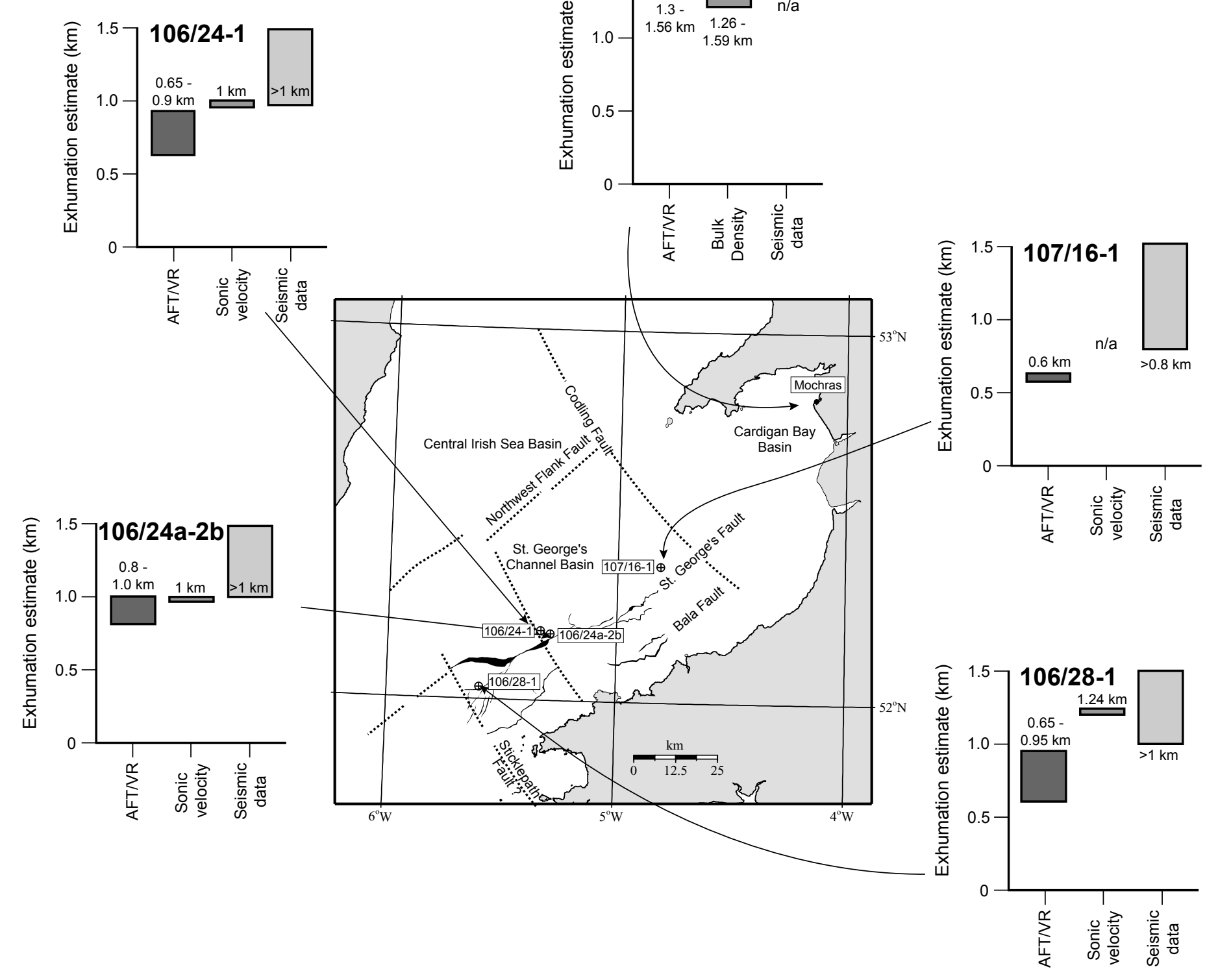




\section{Figure 16}

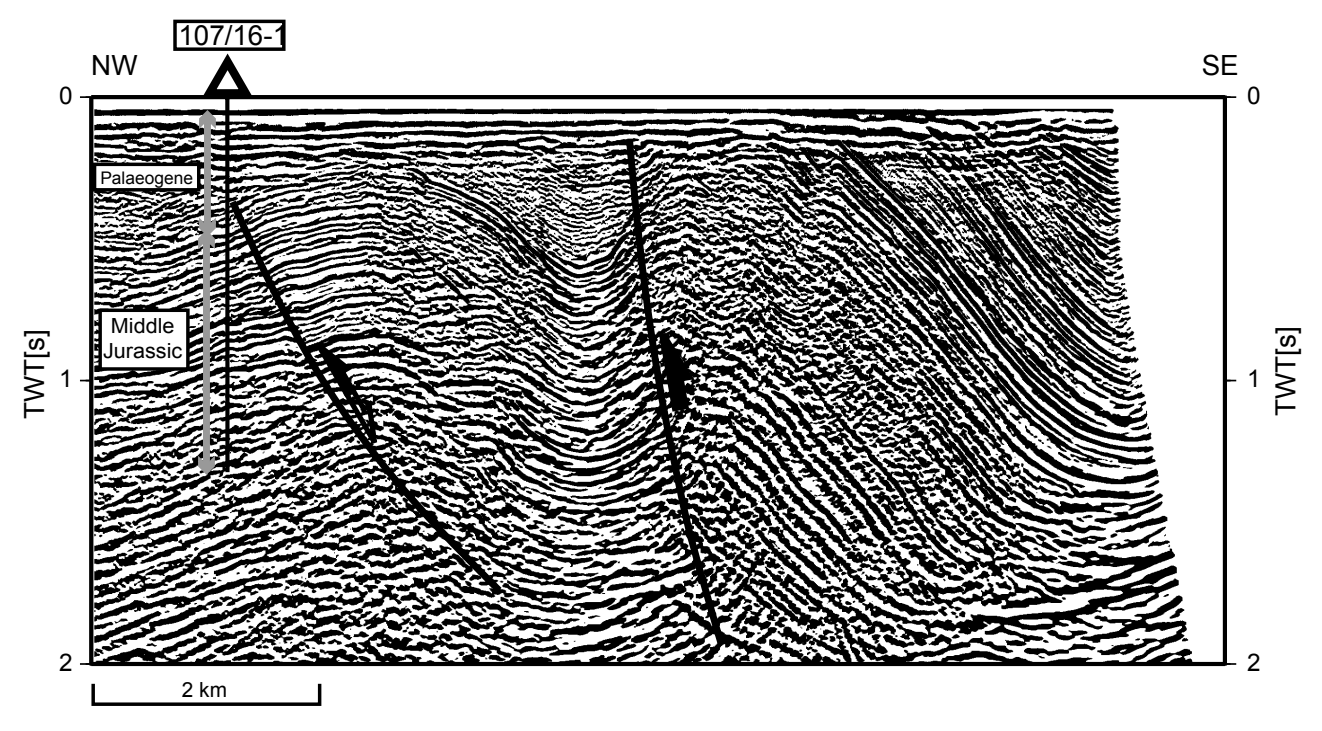




\section{Figure 17}

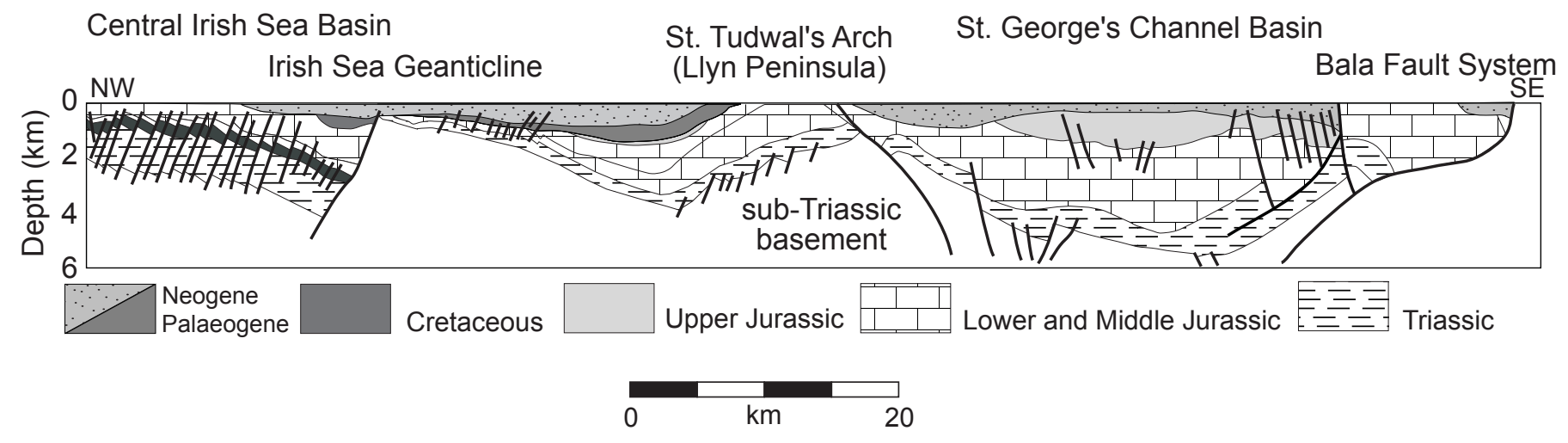




\section{Figure 18}

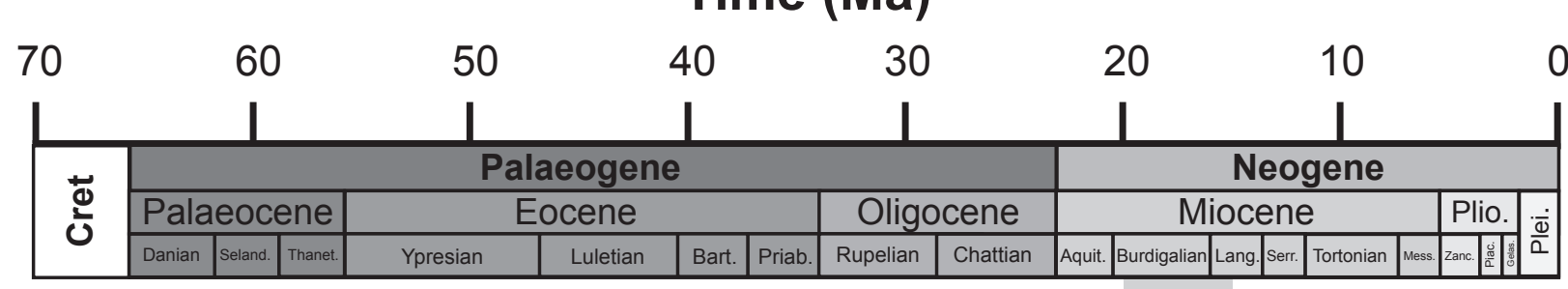

Southern EISB: 30-10 Ma

Northern EISB: 30-5 Ma

Mochras: 50-0 Ma

Central Irish Sea Basin: 25-0 Ma

Kish Bank Basin: 50-10 Ma

Larne No. 2: 35-5 Ma

Onshore Ireland: 25-15 Ma

Midland Platform: 25-0 Ma

East Midlands Shelf: $40-5 \mathrm{Ma}$

UK Atlantic

Margin : 55-10 Ma

Stratigraphic constraints on timing of exhumation

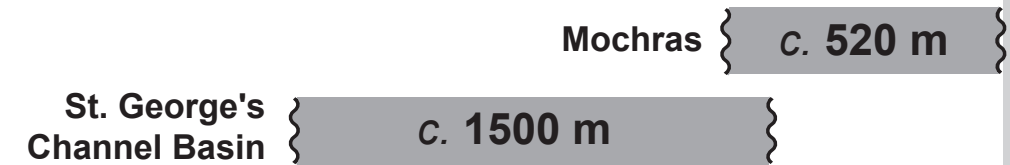

OVERALL CONSTRAINT ON TIMING = 20-15 Ma

Compressional

Unconformities

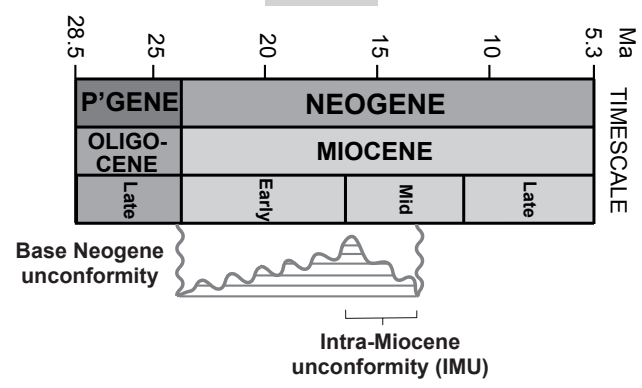

the Atlantic Margin

Inversion domes

e.g. Helland-Hansen Arch,
Fugloy Ridge, Wyville-Thomso Ridge Complex
Rill

Increase in seafloor
spreading rate

Timing of $---\overleftrightarrow{\downarrow}--\begin{gathered}\text { Jan Mayen Ridge } \\ \& \text { Greenland }\end{gathered}$ crustal separation $\quad \longleftrightarrow \begin{gathered}\text { S Greenland } \\ \mathrm{NE} \text { Greenland }\end{gathered}$

Plate Tectonics $\&$ other events 